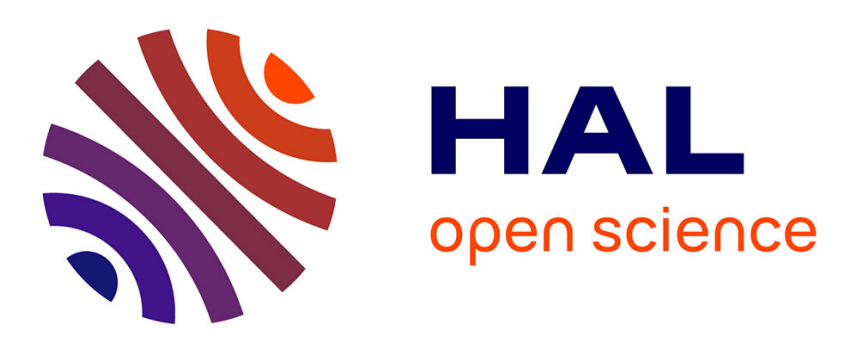

\title{
On the unsuspected role of multivalent metal ions on the charge storage of a metal oxide electrode in mild aqueous electrolytes
}

Yee-Seul Kim, Kenneth R. Harris, Benoit Limoges, Véronique Balland

\section{- To cite this version:}

Yee-Seul Kim, Kenneth R. Harris, Benoit Limoges, Véronique Balland. On the unsuspected role of multivalent metal ions on the charge storage of a metal oxide electrode in mild aqueous electrolytes. Chemical Science, 2019, 10 (38), pp.8752-8763. 10.1039/C9SC02397F . hal-02390810

\author{
HAL Id: hal-02390810 \\ https://hal.science/hal-02390810
}

Submitted on 3 Dec 2019

HAL is a multi-disciplinary open access archive for the deposit and dissemination of scientific research documents, whether they are published or not. The documents may come from teaching and research institutions in France or abroad, or from public or private research centers.
L'archive ouverte pluridisciplinaire HAL, est destinée au dépôt et à la diffusion de documents scientifiques de niveau recherche, publiés ou non, émanant des établissements d'enseignement et de recherche français ou étrangers, des laboratoires publics ou privés. 


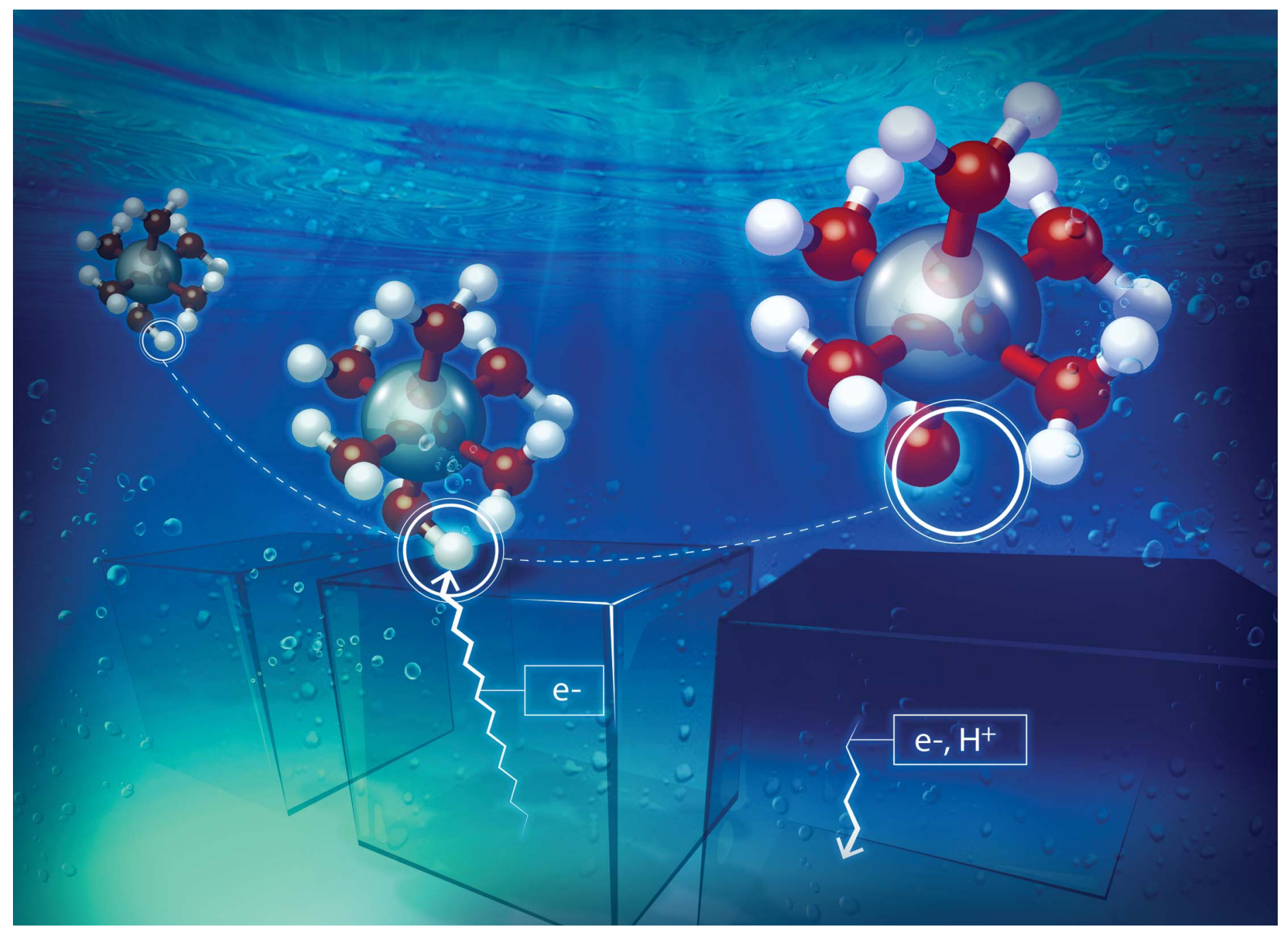

Showcasing research from B. Limoges and V. Balland, Laboratory of Molecular Electrochemistry, Université de Paris-CNRS, France.

On the unsuspected role of multivalent metal ions on the charge storage of a metal oxide electrode in mild aqueous electrolytes

In the present work, we highlight the ability of multivalent metal cations commonly involved in rechargeable aqueous batteries to behave as Brønsted weak acids once solubilized in an aqueous electrolyte. They can thus act as efficient proton donors to induce fast, massive, and reversible proton insertion at metal oxide electrodes. This result sheds new light on previous studies assuming reversible $\mathrm{Al}^{3+}$-insertion into metal oxides such as $\mathrm{TiO}_{2}$. More generally, it demonstrates that the weak acidity of $\left[\mathrm{M}\left(\mathrm{H}_{2} \mathrm{O}\right)_{x}\right]^{\mathrm{nt}}$ plays a fundamental role in the charge storage of metal oxide electrode materials.

\section{As featured in:}

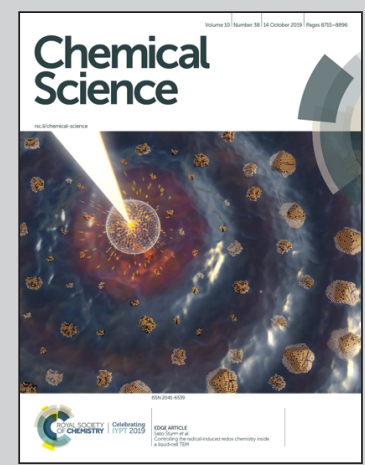

See Benoît Limoges,

Véronique Balland et al.,

Chem. Sci., 2019, 10, 8752. 


\section{EDGE ARTICLE}

\section{Check for updates}

Cite this: Chem. Sci., 2019, 10, 8752

¿ All publication charges for this article have been paid for by the Royal Society of Chemistry
Received 16th May 2019

Accepted 5th August 2019

DOI: $10.1039 / c 9 s c 02397 f$

rsc.li/chemical-science

\section{On the unsuspected role of multivalent metal ions on the charge storage of a metal oxide electrode in mild aqueous electrolytes $\uparrow$}

\author{
Yee-Seul Kim, ${ }^{a}$ Kenneth D. Harris, ${ }^{\text {bc }}$ Benoît Limoges (D) *a and Véronique Balland (DD *a
}

Insertion mechanisms of multivalent ions in transition metal oxide cathodes are poorly understood and subject to controversy and debate, especially when performed in aqueous electrolytes. To address this issue, we have here investigated the reversible reduction of nanostructured amorphous $\mathrm{TiO}_{2}$ electrodes by spectroelectrochemistry in mild aqueous electrolytes containing either a multivalent metal salt as $\mathrm{AlCl}_{3}$ or a weak organic acid as acetic acid. Our results show that the reversible charge storage in $\mathrm{TiO}_{2}$ is thermodynamically and kinetically indistinguishable when carried out in either an $\mathrm{Al}^{3+}$ - or acetic acidbased electrolyte, both leading under similar conditions of $\mathrm{pH}$ and concentrations to an almost identical maximal charge storage of $\sim 115 \mathrm{~mA} \mathrm{~h} \mathrm{~g}$. These observations are in agreement with a mechanism where the inserting/deinserting cation is the proton and not the multivalent metal cation. Analysis of the data also demonstrates that the proton source is the Brønsted weak acid present in the aqueous electrolyte, i.e. either the acetic acid or the aquo metal ion complex generated from solvation of $\mathrm{Al}^{3+}$ (i.e. $\left.\left[\mathrm{Al}\left(\mathrm{H}_{2} \mathrm{O}\right)_{6}\right]^{3+}\right)$. Such a proton-coupled charge storage mechanism is also found to occur with other multivalent metal ions such as $\mathrm{Zn}^{2+}$ and $\mathrm{Mn}^{2+}$, albeit with a lower efficiency than $\mathrm{Al}^{3+}$, an effect we have attributed to the lower acidity of $\left[\mathrm{Zn}\left(\mathrm{H}_{2} \mathrm{O}\right)_{6}\right]^{2+}$ and $\left[\mathrm{Mn}\left(\mathrm{H}_{2} \mathrm{O}\right)_{6}\right]^{2+}$. These findings are of fundamental importance because they shed new light on previous studies assuming reversible $\mathrm{Al}^{3+}$-insertion into metal oxides, and, more generally, they highlight the unsuspected proton donor role played by multivalent metal cations commonly involved in rechargeable aqueous batteries.

\section{Introduction}

Intercalation batteries based on the pairing of a multivalent metallic conversion anode $(\mathrm{Mg}, \mathrm{Zn}, \mathrm{Al}$, etc.) with a multivalent metal ion-insertion cathode (i.e., electrode materials able to accommodate the reversible insertion of $\mathrm{Mg}^{2+}, \mathrm{Zn}^{2+}, \mathrm{Al}^{3+}$, etc.) are an attractive alternative to rechargeable Li-ion batteries for grid-scale applications. These intercalation batteries have the potential for high-energy density (because of the multiple electrons involved at the anode), low cost (many multivalent metal ions are earth-abundant and relatively inexpensive to mine), and possibly long cycle life..$^{\mathbf{1 - 4}}$ Moreover, if operating in aqueous electrolytes, these intercalation batteries can offer additional advantages of sustainability, eco-compatibility, safety, and ease of fabrication at large scale.

\footnotetext{
${ }^{a}$ Université de Paris, Laboratoire d'Electrochimie Moléculaire, UMR 7591, CNRS, F-75013 Paris, France. E-mail: limoges@univ-paris-diderot.fr; veronique.balland@ univ-paris-diderot.fr

${ }^{b} N R C$ Nanotechnology Research Centre, Edmonton, Alberta T6G 2M9, Canada 'Department of Mechanical Engineering, University of Alberta, Edmonton, Alberta T6G 2V4, Canada

$\dagger$ Electronic supplementary information (ESI) available. See DOI: $10.1039 / \mathrm{c} 9 \mathrm{sc} 02397 \mathrm{f}$
}

To date, a variety of aqueous batteries based on naturallyabundant multivalent metal ions $\left(\mathrm{Zn}^{2+}, \mathrm{Mg}^{2+}, \mathrm{Al}^{3+} \ldots\right)$ have been proposed (still in the experimental stage) and significant milestones have been achieved over the past few years. ${ }^{\mathbf{1} 3-6}$ For instance, remarkably high energy densities (ranging from 150 to $200 \mathrm{~W} \mathrm{~h} \mathrm{~kg}^{-1}$ ) with excellent capacity retentions (>80\% over a few thousands cycles) and rate capabilities have been obtained for a range of rechargeable aqueous zinc-ion batteries paired with different intercalation metal oxide cathodes in mild aqueous electrolyte conditions (from near neutral to slightly acidic pHs).$^{7-13}$ In these studies, the soluble metal ion $\left(\mathrm{Zn}^{2+}\right)$ present in the electrolyte has been shown to be responsible for the reversible faradaic processes at the host electrode material, as evidenced by well-defined reversible waves in cyclic voltammetry $(\mathrm{CV})$ and plateaus in galvanostatic experiments. The exact mechanism of charge storage, however, remains obscure and a matter of debate. By analogy with Li-ion batteries, it is often claimed that the charge storage arises from reversible intercalation/insertion of the aqueous multivalent metal cation within the metal oxide cathode. ${ }^{1}$ However, despite numerous attempts to establish the presence of intercalated multivalent cations via structural characterization, none of the studies to date have unambiguously demonstrated the intercalation/ insertion mechanism. Additionally, in contrast to the high- 
charge storage capacities persistently achieved in aqueous electrolytes for a range of metal oxides hosts (i.e., manganese oxides, vanadium oxides, titanium oxides, and tungsten oxides) with different soluble multivalent metal cations $\left(\mathrm{Zn}^{2+}, \mathrm{Mg}^{2+}\right.$ and even $\mathrm{Al}^{3+}$ ), for unknown reasons, tiny capacities were systematically retrieved for the same systems in water-free organic electrolytes. ${ }^{7, \mathbf{1 4 - 2 0}}$ These poor electrochemical performances in non-aqueous electrolytes support the assumption that multivalent cations cannot readily insert in metal oxides because of their excessively strong coulombic interactions with the oxide host lattices. Difficulties are also imposed as the oxidation state of the solid structure changes to redistribute the charge of the inserted multivalent cations; this process is presumed to result in a drastic local deformation in the host crystal structure concomitant with a sudden adjustment in the coordination environment and bond lengths. ${ }^{21,22}$

Among the multivalent ions, the $\mathrm{Al}^{3+}$ ion is a particularly intriguing case. The benefit of $\mathrm{Al}^{3+}$-based electrolytes on the charge storage capacity of many metal oxide cathodes has been unequivocally revealed. ${ }^{15,23-33}$ This was first reported in 2012 by Gao and colleagues ${ }^{23}$ for anatase $\mathrm{TiO}_{2}$ nanotubes in a $1 \mathrm{M} \mathrm{AlCl}_{3}$ aqueous electrolyte. The reversible $\mathrm{CV}$ peaks as well as the significant capacity $\left(75 \mathrm{~mA} \mathrm{~h} \mathrm{~g}^{-1}\right.$ at $4 \mathrm{~mA} \mathrm{~cm}^{-2}$ ) recovered from galvanostatic experiments were attributed to the reversible formation of the $\mathrm{Al}_{0.076} \mathrm{TiO}_{2}$ intercalation compound. ${ }^{23}$ Similar observations were also made by other groups (see Table 1 ). ${ }^{\mathbf{2 6 - 2 8}}$ The capacity was thereafter significantly improved using composite electrode materials incorporating black anatase $\mathrm{TiO}_{2}$ nanoleaves or anatase $\mathrm{TiO}_{2}$ nanospheres, reaching maximal capacities $>200 \mathrm{~mA} \mathrm{~h} \mathrm{~g}^{-1}$ in $1 \mathrm{M} \mathrm{Al}\left(\mathrm{NO}_{3}\right)_{3}$ or $1 \mathrm{M} \mathrm{AlCl}_{3}$ aqueous electrolytes (attributed thus to the formation of $\mathrm{Al}_{>0.2} \mathrm{TiO}_{2}$ ). ${ }^{29,30,34}$ Furthermore, along with these high gravimetric capacities, high rate capability (141 $\mathrm{mA} \mathrm{h} \mathrm{g}^{-1}$ at $6 \mathrm{C}$ ) with reasonably good cyclability ( $>300$ cycles) were found..$^{29}$ In order to demonstrate $\mathrm{Al}^{3+}$ insertion in the $\mathrm{TiO}_{2}$ structure, different structural analyses have been undertaken, however, the results were generally inconclusive: the XPS peak of $\mathrm{Al}^{3+}$ in the reduced phase of $\mathrm{TiO}_{2}$ is barely discernable, ${ }^{23,26,27}$ and no significant differences between the XRD spectra of the oxidized and reduced $\mathrm{TiO}_{2}$ were observed. ${ }^{23,29}$ Besides $\mathrm{TiO}_{2}$, the advantageous effect of $\mathrm{Al}^{3+}$ based aqueous electrolytes has also been reported with other metal oxide electrodes such as $\mathrm{WO}_{3}$ nanowire films, ${ }^{15,31}$ $\mathrm{MnO}_{2},{ }^{32,33}$ conductive polymer-coated $\mathrm{MoO}_{3},{ }^{24}$ and $\mathrm{V}_{2} \mathrm{O}_{5}$ xerogels, ${ }^{25}$ but again, insertion of $\mathrm{Al}^{3+}$ within the metal oxide matrix has yet to be conclusively established.

One argument frequently used to support the insertion of $\mathrm{Al}^{3+}$ in metal oxide cathodes is the smaller ionic radius of $\mathrm{Al}^{3+}(54 \mathrm{pm})$ compared to $\mathrm{Li}^{+}$(76 pm). This argument, however, does not take into account the strong desolvation energy associated with the highly positively charged $\mathrm{Al}^{3+}$ ion, especially in water. ${ }^{35}$ Also, it does not consider the particularly strong coulombic interactions between the highly charged $\mathrm{Al}^{3+}$ and the surrounding metal oxide lattice, an effect that is assumed to considerably impede solidstate diffusion. By computing the theoretical migration energy barriers of multivalent ions such as $\mathrm{Al}^{3+}, \mathrm{Mg}^{2+}, \mathrm{Zn}^{2+}, \mathrm{Ca}^{2+}$ in $\mathrm{Mn}_{2} \mathrm{O}_{4}$ or $\mathrm{V}_{2} \mathrm{O}_{5}$, Ceder and colleagues concluded that there is little hope of intercalating $\mathrm{Al}^{3+}$ in common metal oxide hosts at room temperature. ${ }^{36}$ An additional possibility is competitive proton intercalation, which can occur naturally in aqueous environments upon dissolution of aluminum salts at molar concentrations $\mathrm{pH}$ $<3),{ }^{27}$ or be easily triggered from side reactions (e.g., electrolysis of water) or deprotonation of Brønsted weak acids. ${ }^{37}$

All of this shows that many unanswered fundamental questions remain to be elucidated if one wants to better understand the role played by multivalent ions in the storage of charges in metal oxides, especially in aqueous electrolytes. The particularly

Table 1 Comparison of the electrochemical properties of nanostructured $\mathrm{TiO}_{2}$ electrodes in the presence of various aluminum salts in aqueous solutions. The performances obtained at $\mathrm{GLAD}-\mathrm{TiO}_{2}$ electrodes in the presence of a weak acid are also added (all potentials are quoted vs. Ag/ $\mathrm{AgCl}$ ) for comparison.

\begin{tabular}{|c|c|c|c|c|c|c|c|c|}
\hline $\begin{array}{l}\text { Film } \\
\text { morphology }\end{array}$ & $\begin{array}{l}\mathrm{TiO}_{2} \\
\text { crystallinity }\end{array}$ & Electrolyte & $\mathrm{pH}^{a}$ & $E^{0^{\prime} b}(\mathrm{~V})$ & $\begin{array}{l}\text { Maximal capacity } \\
\left(\mathrm{mA} \mathrm{h} \mathrm{g}^{-1}\right)\end{array}$ & $\begin{array}{l}\text { Charging rate } \\
\left(\mathrm{A} \mathrm{g}^{-1}\right)\end{array}$ & $\begin{array}{l}\text { Charging cut-off } \\
\text { potential (V) }\end{array}$ & Ref. \\
\hline Nanotubes & Anatase & $1 \mathrm{M} \mathrm{AlCl}_{3}$ & $\mathrm{nr}$ & -1.05 & 75 & $4 \mathrm{~mA} \mathrm{~cm}^{-2}$ & -1.2 & 23 \\
\hline Nanotubes & Anatase & $\begin{array}{l}\text { Up to } 0.5 \mathrm{M} \mathrm{AlCl}_{3} \\
\text { or } \mathrm{Al}_{2}\left(\mathrm{SO}_{4}\right)_{3}\end{array}$ & 2.5 & -1.1 & 75 & $4 \mathrm{~mA} \mathrm{~cm} \mathrm{~cm}^{-2}$ & -1.15 & 26 \\
\hline Nanoleaves ${ }^{c}$ & Black anatase & $1 \mathrm{M} \mathrm{Al}\left(\mathrm{NO}_{3}\right)_{3}$ & $\mathrm{nr}$ & -1.05 & $\begin{array}{l}278 \\
141\end{array}$ & $\begin{array}{l}0.05 \\
2\end{array}$ & -1.4 & 29 \\
\hline Nanospheres $^{c}$ & Anatase & $1 \mathrm{M} \mathrm{AlCl}_{3}$ & $\mathrm{nr}$ & -1.06 & 183 & 0.05 & -1.2 & 30 \\
\hline Nanotubes $^{d}$ & Anatase & $\begin{array}{l}1 \mathrm{M} \mathrm{AlCl}_{3} \\
0.25 \mathrm{M} \mathrm{AlCl}_{3}\end{array}$ & $\begin{array}{l}3 \\
3.8\end{array}$ & -1.13 & $\begin{array}{l}33 \\
50\end{array}$ & $\begin{array}{l}6.25 \\
6.25\end{array}$ & -1.075 & 28 \\
\hline Nanoparticles $^{e}$ & Anatase & $1 \mathrm{M} \mathrm{AlCl}_{3}$ & $\leq 3$ & -1.07 & $\begin{array}{l}225 \\
135\end{array}$ & $\begin{array}{l}0.05 \\
2\end{array}$ & -1.2 & 34 \\
\hline Nanocolumns ${ }^{f}$ & Amorphous & $\begin{array}{l}0.25 \mathrm{AlCl}_{3} \\
0.25 \mathrm{M} \mathrm{KCl} \\
0.25 \mathrm{M} \mathrm{acetic} \text { acid }+0.3 \\
\mathrm{M} \mathrm{KCl}\end{array}$ & $\begin{array}{l}3 \\
3 \\
3\end{array}$ & $\begin{array}{l}-0.75 \\
-0.75\end{array}$ & $\begin{array}{l}115 \\
25 \\
118\end{array}$ & $\begin{array}{l}1.6 \\
1.6 \\
1.6\end{array}$ & $\begin{array}{l}-1.12 \\
-1.12 \\
-1.12\end{array}$ & $\begin{array}{l}\text { This work } \\
\text { This work } \\
\text { This work }\end{array}$ \\
\hline
\end{tabular}

${ }^{a} \mathrm{nr}=$ not reported. ${ }^{b}$ Formal potential of the reversible insertion wave in CV. ${ }^{c}$ Composite electrodes with acetylene black. ${ }^{d}$ Composite electrodes

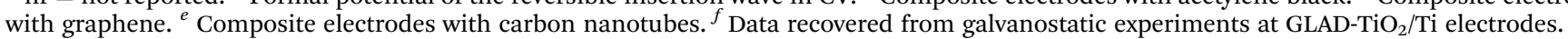


striking case posed by $\mathrm{Al}^{3+}$ (i.e., can be inserted into a threedimensional crystalline structure such as $\mathrm{TiO}_{2}$ ) has pushed us to carry out an in-depth study of this system in aqueous media. In this study, we seek to draw knowledge that can then be transposed to other multivalent ion/metal oxide systems. The additional advantage of working with $\mathrm{TiO}_{2}$ is its rather simple solid-state redox chemistry, centered on a single reversible redox transition from $\mathrm{Ti}^{\mathrm{IV}}$ and $\mathrm{Ti}^{\mathrm{III}}$. Its excellent chemical stability in aqueous media over a wide range of $\mathrm{pHs}$ is a further advantage, avoiding many complications commonly encountered with electrodissolution and/or electrodeposition of metal oxides such as manganese oxides or vanadium oxides in aqueous electrolytes. ${ }^{38}$ The main objective of this work is therefore to elucidate and rationalize the role played by an $\mathrm{Al}^{3+}$ based aqueous electrolyte on the charge accumulated in model mesoporous $\mathrm{TiO}_{2}$ electrodes and to decipher the chemical nature of the inserting cation. As will be shown, the present results strongly support a charge storage mechanism exclusively based on proton insertion in $\mathrm{TiO}_{2}$, wherein the hexaaquo complex $\left[\mathrm{Al}\left(\mathrm{H}_{2} \mathrm{O}\right)_{6}\right]^{3+}$ (generated upon solvation of the $\mathrm{Al}^{3+}$ inorganic salt in the aqueous electrolyte) behaves as a proton donor at the metal oxide/electrolyte interface. This reactivity is also demonstrated for other multivalent metal ions such as $\mathrm{Zn}^{2+}$ and $\mathrm{Mn}^{2+}$, which in their hexahydrated forms, can play the role of a proton donor in water. This original result demonstrates that the Brønsted acidity of $\left[\mathrm{M}\left(\mathrm{H}_{2} \mathrm{O}\right)_{6}\right]^{n+}$ complexes can play a fundamental role in the charge storage of metal oxide electrode materials and that it must be taken into account when analyzing the charge storage mechanisms at rechargeable batteries combining metal salts and water molecules.

\section{Materials and methods}

\subsection{Chemicals and materials}

Aluminum chloride hexahydrate $\left(\mathrm{AlCl}_{3} \cdot 6 \mathrm{H}_{2} \mathrm{O}\right)$ and zinc chloride tetrahydrate $\left(\mathrm{ZnCl}_{2} \cdot 4 \mathrm{H}_{2} \mathrm{O}\right)$ were purchased from Sigma-Aldrich. Manganese chloride tetrahydrate $\left(\mathrm{MnCl}_{2} \cdot 4 \mathrm{H}_{2} \mathrm{O}\right)$ was purchased from Alfa Aesar. Potassium hydroxide, acetic acid (100\%, AnalaR NORMAPUR ${ }^{\circledR}$ ) and hydrochloric acid (37 wt\%) were obtained from VWR Prolabo. Potassium chloride (Merck \& Co., puriss. p.a.) was used as received. All aqueous solutions were made with deionized water $(18.2 \mathrm{M} \Omega \mathrm{cm})$ from a TKA MicroPure UV purification system.

\subsection{Mesoporous GLAD-TiO electrodes $^{2}$}

Nanostructured electrodes were prepared by physical vapor deposition of a mesoporous amorphous $\mathrm{TiO}_{2}$ film using a glancing angle deposition (GLAD) approach. Two different electrode types, denoted $\mathrm{GLAD}-\mathrm{TiO}_{2} / \mathrm{TiO}_{2} / \mathrm{ITO}$ and $\mathrm{GLAD}-\mathrm{TiO}_{2} / \mathrm{Ti}$, were prepared. In the first case, the conductive side of tin-doped indium oxide (ITO) coated glass (Delta Technologies, 8-12 $\Omega$ $\square^{-1}$ ) was coated with a thin layer of bulk $\mathrm{TiO}_{2}$ (15 nm-thick) by conventional (i.e., non-GLAD) e-beam evaporation, followed by $\mathrm{GLAD}^{-\mathrm{TiO}_{2}}$. For GLAD-TiO $/ \mathrm{Ti}$, clean glass substrates were coated with $250 \mathrm{~nm}$ of bulk Ti, followed by $\mathrm{GLAD}^{-\mathrm{TiO}_{2}}$. In each case, the GLAD- $\mathrm{TiO}_{2}$ process was performed at a fixed oblique angle of $72^{\circ}$ while continuously rotating the substrate at a rate of one complete rotation for every $10 \mathrm{~nm}$ of $\mathrm{TiO}_{2}$ film growth until the mesoporous $\mathrm{TiO}_{2}$ film was $1 \mu$ m-thick. GLAD-TiO ${ }_{2} / \mathrm{TiO}_{2} / \mathrm{ITO}$ electrodes were thermally annealed at $100{ }^{\circ} \mathrm{C}$ for 24 hours in order to increase the oxygen content and improve transparency. Prior to use, electrodes were cleaned in an ultraviolet ozone cleaner ( $\mathrm{UV} / \mathrm{O}_{3}$ Procleaner ${ }^{\mathrm{TM}}$ plus, Bioforce Nanosciences) for $15 \mathrm{~min}$ to remove surface contaminants and subsequently soaked at room temperature in acetone and then ethanol for 15 and $30 \mathrm{~min}$, respectively. The electroactive $\mathrm{TiO}_{2}$ surface was delimited by depositing nail vanish to define a rectangular working electrode area of $0.5 \pm 0.05 \mathrm{~cm}^{2}$ (evaluated from a set of $N=15$ independent electrodes).

\subsection{Spectroelectrochemical and electrochemical experiments}

Spectroelectrochemical experiments were performed with an Autolab PGSTAT-12 potentiostat (operated by GPES-4 software) synchronized through an input trigger signal to a fiber-coupled TORUS UV-visible spectrophotometer (Ocean Optics). This setup allows simultaneous monitoring of the electrochemical current and optical absorbance at a GLAD-TiO ${ }_{2}$ electrode during any type of electrochemical experiment. A balanced deuterium tungsten source (Micropack) was used for illumination, and an integration time of $3 \mathrm{~ms}$ was used for UV-vis spectral acquisition. The spectroelectrochemical cell (Fig. S2 $\dagger$ ) was thermostated at a temperature of $25^{\circ} \mathrm{C}$ using a dedicated Peltier-heater (Quantum Northwest). In order to avoid faradaic contribution arising from $\mathrm{O}_{2}$ reduction, the electrolyte solution was thoroughly deaerated by argon bubbling (for at least $10 \mathrm{~min}$ ) before each experiment, and a constant flux of argon was maintained above the solution during experiments. An $\mathrm{Ag} / \mathrm{AgCl}$ electrode filled with an internal saturated $\mathrm{KCl}$ solution (WPI, Dri-Ref, $+0.2 \mathrm{~V} v s$. NHE at $25^{\circ} \mathrm{C}$ ) and a Pt wire were used as the reference and counter electrodes, respectively. An average ohmic drop compensation of $41 \pm 4 \Omega(N=24)$ was applied to the electrochemical experiments (except for the potential step experiments, vide infra).

In cyclic voltabsorptometry experiments, a satisfactory absorbance signal-to-noise ratio was obtained by averaging 12 scans for the experiments performed at $50 \mathrm{mV} \mathrm{s}^{-1}, 6$ scans for those at $100 \mathrm{mV} \mathrm{s}^{-1}$, and 4 scans for those at $200 \mathrm{mV} \mathrm{s}^{-1}$. The extinction coefficient of the charges accumulated in $\mathrm{TiO}_{2}$ at $\lambda=$ $780 \mathrm{~nm}$ was recovered from the following relationship (expressed here in flux density, $\phi$, or mol cm $\mathrm{cm}^{-2} \mathrm{~s}^{-1}$ ) relating the measured current to the absorbance change:

$$
\phi=\frac{1}{1000 \times \varepsilon_{780}} \frac{\mathrm{d} A_{780}}{\mathrm{~d} t}=\frac{i}{F S}
$$

where $A_{780}$ is the absorbance monitored at $780 \mathrm{~nm}, F$ is the Faraday constant (96 $485 \mathrm{C} \mathrm{mol}^{-1}$ ), $S$ the geometric electroactive surface area (in $\mathrm{cm}^{2}$ ) and $\varepsilon_{780}$ is the extinction coefficient (in $\mathrm{M}^{-1} \mathrm{~cm}^{-1}$ ) of the stored charges. As a function of the electrode used, $\varepsilon_{780}$ values ranging from 900 to $1200 \mathrm{M}^{-1} \mathrm{~cm}^{-1}$ were obtained, which is in agreement with the values previously reported by us and others. ${ }^{37,39-41}$ 
Galvanostatic experiments were performed with current densities ranging from $0.4 \mathrm{~mA} \mathrm{~cm}^{-2}$ to $2 \mathrm{~mA} \mathrm{~cm}^{-2}$ and cut-off charge voltages ranging from $+0.24 \mathrm{~V}$ to $-1.12 \mathrm{~V} v s$. $\mathrm{Ag} / \mathrm{AgCl}$ at pH 3.

Whatever the electrochemical technique used, the charge density $Q$ (in $\mathrm{mC} \mathrm{cm}^{-2}$ ) accumulated in the $\mathrm{GLAD}^{-\mathrm{TiO}_{2}}$ film was determined from the maximal absorbance change monitored at $780 \mathrm{~nm}$ using the following expression:

$$
Q=F \frac{\Delta A_{780}}{1000 \times \varepsilon_{780}}=\int \frac{i}{S} \mathrm{~d} t
$$

From the values determined for $Q$, the corresponding gravimetric capacity (in $\mathrm{mC}^{-1}$ or $\mathrm{mA} \mathrm{h} \mathrm{g}^{-1}$ ) was calculated by taking into account the volumetric mass density of the GLAD$\mathrm{TiO}_{2}$ film (i.e. $2.5 \times 10^{-4} \mathrm{~g} \mathrm{~cm}^{-2}$ for the $1 \mu \mathrm{m}$-thick GLAD-TiO ${ }_{2}$ film). ${ }^{42}$ The gravimetric capacity arising exclusively from ion intercalation in $\mathrm{TiO}_{2}$ was determined after correcting for the amount of capacitive charges stored at the $\mathrm{TiO}_{2} /$ electrolyte interface in an inert $0.3 \mathrm{M} \mathrm{KCl}$ aqueous electrolyte (adjusted to $\mathrm{pH} 3.0)$.

\section{Results and discussion}

\subsection{Model GLAD-TiO ${ }_{2}$ electrodes}

Model mesoporous metal oxide electrodes were composed of a 1 $\mu \mathrm{m}$ thick nanostructured amorphous $\mathrm{TiO}_{2}$ film. In contrast with the composite electrode materials commonly used for batteries (i.e., mixtures of active material, binder and conductive additives), these $\mathrm{TiO}_{2}$ electrodes are exclusively composed of active material. The nanostructured $\mathrm{TiO}_{2}$ film was obtained by glancing angle deposition (GLAD), ${ }^{\mathbf{4 2 , 4 3}}$ a physical vapor deposition technique that leads to highly reproducible nanostructured metal oxide films of vertically aligned nanocolumns with wellcontrolled porosity and thickness. We have recently shown that protons can be rapidly and massively inserted/disinserted in these $\mathrm{GLAD}^{-\mathrm{TiO}_{2}}$ electrodes, negatively polarized in a neutral aqueous buffer. ${ }^{37}$ In this previous work, we also demonstrated that the inserted protons originate from the weak conjugate acid of the organic buffer present in solution at neutral $\mathrm{pH}$. This is markedly different from proton insertion in a strongly acidic aqueous electrolyte (typically $\mathrm{pH}<2$ ) where free protons (or more rigorously hydronium ions) naturally serve as a proton source..$^{37,44}$

For the present study, two different types of $1 \mu \mathrm{m}$-thick $\mathrm{GLAD}^{-\mathrm{TiO}_{2}}$ electrodes were used (Fig. S1†): (i) $1 \mu \mathrm{m}$-thick amorphous $\mathrm{TiO}_{2}$ mesoporous film deposited by GLAD (using a deposition angle of $72^{\circ}$ ) over flat transparent conductive ITOcoated glass surfaces (GLAD- $\mathrm{TiO}_{2} / \mathrm{TiO}_{2} / \mathrm{ITO}$ electrodes), and (ii) the same $1 \mu$ m-thick GLAD $\mathrm{TiO}_{2}$ film deposited over a nontransparent conductive Ti-coated glass surfaces $\left(\mathrm{GLAD}^{-\mathrm{TiO}} \mathrm{O}_{2} / \mathrm{Ti}\right.$ electrodes) (see Materials and methods for details). In the case of the GLAD- $\mathrm{TiO}_{2} / \mathrm{TiO}_{2} / \mathrm{ITO}$ electrodes, before the GLAD mesoporous $\mathrm{TiO}_{2}$ film deposition, a thin layer of bulk $\mathrm{TiO}_{2}(\sim 15 \mathrm{~nm})$ was deposited over the ITO surface to protect the underlying ITO layer from the electrolyte. Without this $\mathrm{TiO}_{2}$ shielding, the ITO suffers an irreversible loss of conductivity under excessively negative potentials ${ }^{37}$ (see ESI $\dagger$ for additional comments). The GLAD- $\mathrm{TiO}_{2} / \mathrm{TiO}_{2} / \mathrm{ITO}$ electrodes are optically transparent, allowing spectroelectrochemical investigation of storage properties, while the GLAD-TiO $/$ /Ti electrodes exhibit better stability under strongly reducing conditions, allowing investigation of charge storage at more negative potentials. As an illustration, Fig. 1 shows SEM images (top and side views) of a $1 \mu \mathrm{m}$-thick GLAD- $\mathrm{TiO}_{2} / \mathrm{Ti}$ electrode. The surface area enhancement and volumetric mass density of the GLAD $\mathrm{TiO}_{2}$ film are the same as previous reports, i.e. 540 per $\mu \mathrm{m}$ of film thickness and $2.5 \mathrm{~g} \mathrm{~cm}^{-3}$, respectively. ${ }^{42}$

\subsection{Charge storage in the presence of $0.3 \mathrm{M} \mathrm{KCl,} \mathrm{pH} \mathrm{3.0}$}

The electrochemical charge storage properties of the transparent electrodes were characterized by real-time spectroelectrochemistry, a technique which allows absorbance changes (or electrochromic properties) of the $\mathrm{TiO}_{2}$ film to be monitored as a function of cathodic or anodic polarization in a mild aqueous electrolyte (see Materials and methods and Fig. S1 and S2 $\dagger$ ). The electronic properties of amorphous $\mathrm{TiO}_{2}$ are characterized by a bandgap of $\sim 3.2 \mathrm{eV}$ and a $\mathrm{pH}$-dependent conduction band potential of $E_{\mathrm{CB}}=-0.36-0.06 \times \mathrm{pH}(\mathrm{V} v s . \mathrm{Ag} / \mathrm{AgCl}),{ }^{40,45}$ and therefore, the $\mathrm{GLAD}-\mathrm{TiO}_{2} / \mathrm{TiO}_{2} / \mathrm{ITO}$ electrodes exhibit good transparency in the visible range and poor electronic conductivity as long as the applied potential $E \gg E_{\mathrm{CB}}$. As the applied potential $E$ is negatively increased and approaches $E_{\mathrm{CB}}$, light absorbance at the electrode increases concomitant with a rise in conductivity. This behavior is attributed to progressive filling of localized electronic states within the bandgap until $E<E_{\mathrm{CB}}$ is reached and a degenerate state characteristic of a metal-like conductive film is formed. ${ }^{46,47}$

In a $0.3 \mathrm{M} \mathrm{KCl}$ aqueous electrolyte (adjusted to $\mathrm{pH} 3.0$ ), cyclic voltammograms (CVs) and cyclic voltabsorptograms (CVAs, monitored at $780 \mathrm{~nm}$ ) at a $\mathrm{GLAD}-\mathrm{TiO}_{2} / \mathrm{TiO}_{2} / \mathrm{ITO}$ electrode show,

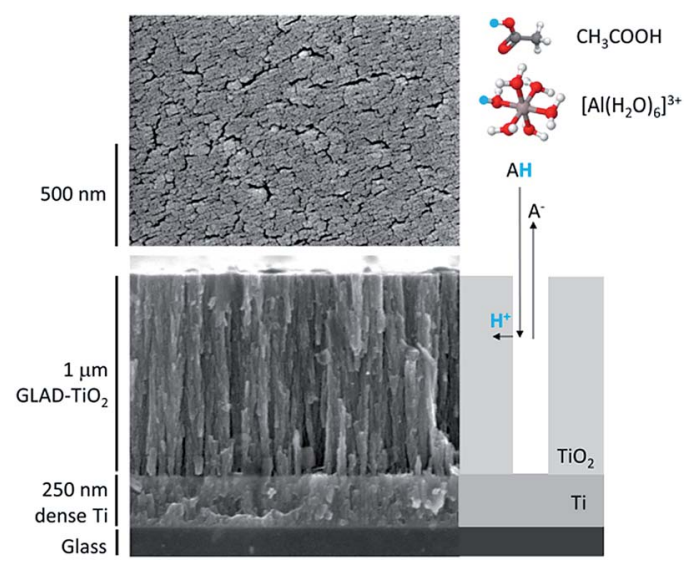

Fig. 1 SEM images (top and side views) of the $1 \mu \mathrm{m}$-thick GLAD- $\mathrm{TiO}_{2} /$ Ti film. At the right of the side view is a schematic representation of the two-step proton insertion mechanism within the nanostructured GLAD $\mathrm{TiO}_{2}$ film. ${ }^{37}$ In this two-step reaction scheme, the proton is provided at the $\mathrm{TiO}_{2}$ /electrolyte interface by either the acetic acid or $\left[\mathrm{Al}\left(\mathrm{H}_{2} \mathrm{O}\right)_{6}\right]^{3+}$, followed by solid-state diffusion/migration throughout the bulk $\mathrm{TiO}_{2}$ lattice. The acidic proton is highlighted in blue. 
as expected, a typical transition from an insulating to a conductive state as the Fermi level of electrons in the $\mathrm{TiO}_{2}$ film increases toward the conduction band potential (a transition which starts here at $\sim-0.3 \mathrm{~V} v s$. $\mathrm{Ag} / \mathrm{AgCl}$ ) (Fig. S1† and 2). This process is associated with a simultaneous increase of the $\mathrm{TiO}_{2}$ film absorbance at $780 \mathrm{~nm}$, which is characteristic of electrons accumulating in the electronic states of the semiconductive material (an increase that is proportional to the amount of charge accumulated within the semiconductive film).$^{39,41,48}$ Once the applied potential lies within the potential window where $\mathrm{TiO}_{2}$ behaves as a metal-like conductive film (i.e., at $E<-0.5 \mathrm{~V} v$. $\mathrm{Ag} / \mathrm{AgCl}$ at $\mathrm{pH} 3.0$ ), the $\mathrm{CV}$ displays a rectangular-shaped current response (Fig. 2A) almost independent of the applied potential and scaling linearly with the scan rate $v$ (Fig. S1 $\dagger$ ). Such a behavior, corroborated by an almost linear and symmetric absorbance change during the forward and backward potential scans in the CVA (Fig. 2A), is characteristic of electrical charging of the double layer capacitance arising from simple ion adsorption at the metal-like- $\mathrm{TiO}_{2} /$ electrolyte interface. ${ }^{49}$ The current density under these conditions is directly proportional to the high surface area of the mesoporous film. ${ }^{37}$ As attested by the complete restoration of the initial metal oxide transparency upon scanning back the potential in the anodic direction, the capacitive charging process is fully reversible.

The maximal amount of charge $(Q)$ that can be stored through the capacitive charging process can be easily inferred from the maximal absorbance change $\left(\Delta A_{\max }\right)$ of the GLAD$\mathrm{TiO}_{2} / \mathrm{TiO}_{2} / \mathrm{ITO}$ electrode at $780 \mathrm{~nm}$ (see Materials and methods). As illustrated in Fig. 2, a maximal $Q$ value of $15 \mathrm{mC} \mathrm{cm}{ }^{-2}$ at $-1.0 \mathrm{~V}$ (i.e., $15 \mathrm{mF} \mathrm{cm} \mathrm{cm}^{-2}$, which is equivalent to $60 \mathrm{~F} \mathrm{~g}^{-1}$ or $17 \mathrm{~mA} \mathrm{~h} \mathrm{~g}^{-1}$ ) can be determined from the cyclic voltabsorptometry experiment, a value that matches those extracted from chronoabsorptometry or galvanostatic experiments (i.e., $\sim 13-$ $14 \mathrm{mC} \mathrm{cm}{ }^{-2}$ at the applied voltage of $-0.82 \mathrm{~V}$, which corresponds to $\sim 16-17 \mathrm{mF} \mathrm{cm}^{-2}$ ) (see blue curves on the bottom graphs of Fig. 2). That the same maximum $Q$ values are obtained, regardless of the technique used, suggests a fast charging process. This is further confirmed by the shape of the chronoabsorptogram in Fig. 2B where the maximal $Q$ value is reached within a few seconds, i.e., on a much shorter time scale than that required to perform $\mathrm{CV}$ or galvanostatic experiments. This behavior fully agrees with that expected for fast charging of the double layer electrical capacitance of a high surface area electrode.
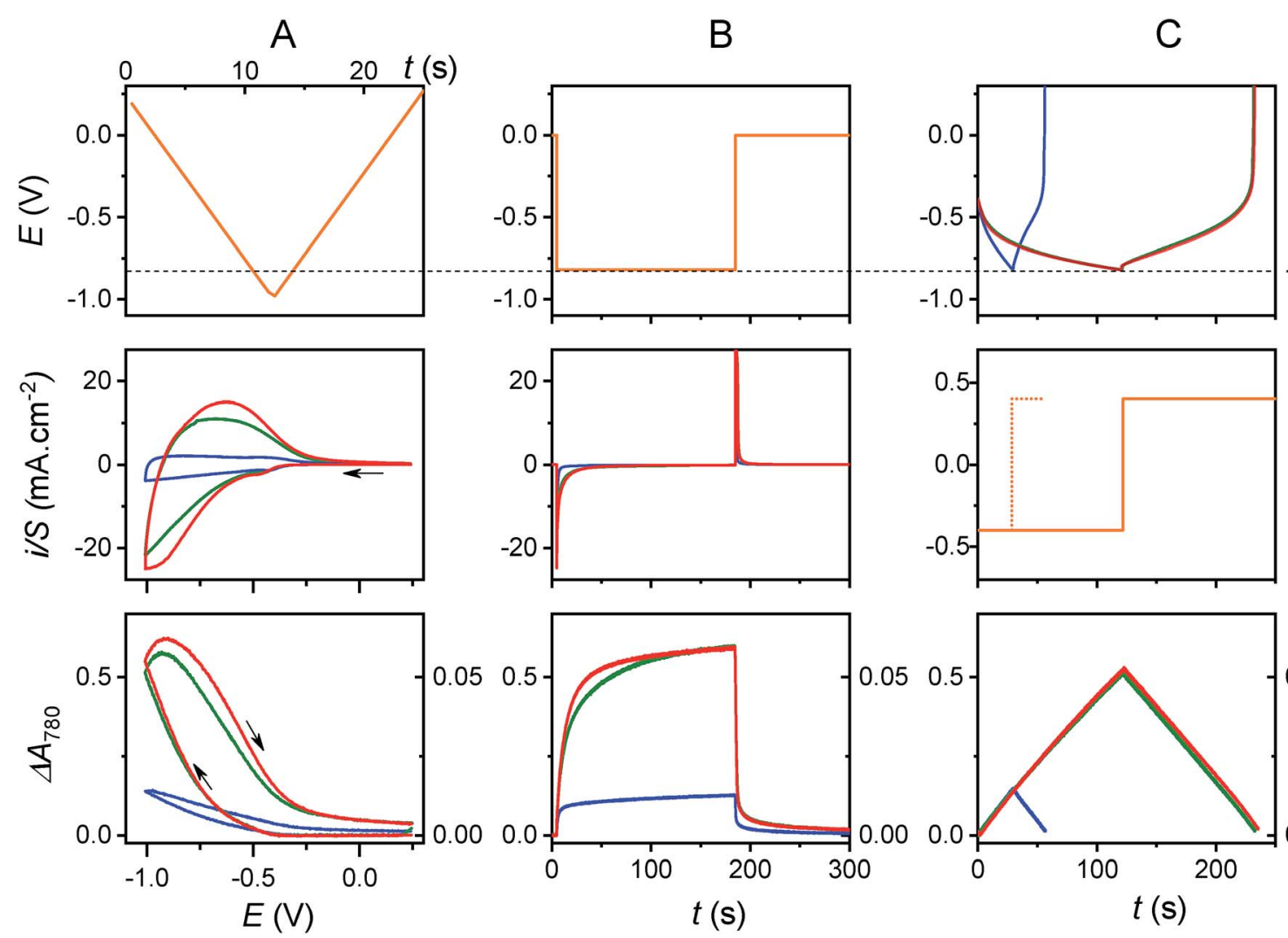

Fig. 2 Spectroelectrochemical characterization of a GLAD- $\mathrm{TiO}_{2} / \mathrm{TiO}_{2} / \mathrm{ITO}$ electrode in an aqueous electrolyte adjusted to $\mathrm{pH} 3.0$ and containing (blue) $0.3 \mathrm{M} \mathrm{KCl}$, (green) $0.25 \mathrm{M}$ acetic acid and $0.3 \mathrm{M} \mathrm{KCl}$, or (red) $0.25 \mathrm{M} \mathrm{AlCl}_{3}$. The orange lines in the top graphs in $\mathrm{A}$ and $\mathrm{B}$ and the middle graph in $\mathrm{C}$ represent the ramps or steps of potential or current which were applied during (A) the cyclic voltammetric, (B) chronoamperometric, and (C) galvanostatic $\left(0.4 \mathrm{~mA} \mathrm{~cm}^{-2}\right)$ experiments. The current density is normalized to the geometric area (S) of the GLAD-TiO, electrode. The charge density $Q$ is directly calculated from the visible absorbance change of the electrode at $780 \mathrm{~nm}$ and normalized to the geometric electrode area (see Materials and methods). The CVs/CVAs were performed at a scan rate $V$ of $0.1 \mathrm{~V} \mathrm{~s}{ }^{-1}$, while the chronoabsorptometric and galvanostatic experiments were carried out at a constant applied potential of $E=-0.82 \mathrm{~V}$ or a constant applied current of $j$ $=0.4 \mathrm{~mA} \mathrm{~cm}^{-2}$. All experiments were performed at $25^{\circ} \mathrm{C}$ and potentials were quoted against the $\mathrm{Ag} / \mathrm{AgCl}$, sat. $\mathrm{KCl}$ reference electrode. 


\subsection{Charge storage in the presence of $0.25 \mathrm{M} \mathrm{AlCl}_{3}, \mathrm{pH}$ 3.0}

In the presence of $\mathrm{AlCl}_{3}$ electrolyte $(0.25 \mathrm{M}, \mathrm{pH} 3)$, the magnitude and shape of the cyclic voltammogram at GLAD-TiO $/ \mathrm{TiO}_{2} /$ ITO electrodes is strongly modified. On top of the abovementioned capacitive current, a broad reversible wave appears, centered on a formal potential of $E^{0 \prime} \sim-0.75 \mathrm{~V}$, and this reversible wave appears together with a large increase in $\mathrm{TiO}_{2}$ film absorbance (Fig. 2). The magnitude of the reversible wave (or reversible absorbance change in CVA) increases with increasing $\mathrm{Al}^{3+}$ concentration in solution (Fig. 3), thus confirming that $\mathrm{Al}^{3+}$ directly contributes to the reversible charge accumulation. Analysis of the cathodic and anodic waves in CV as a function of the scan rate shows that the current is no longer proportional to the scan rate, and that once corrected from the capacitive current (by subtracting the $\mathrm{CV}$ recorded at the same scan rate in the $\mathrm{KCl}$ electrolyte), current is instead proportional to the square root of $v$ over the entire range of $\mathrm{Al}^{3+}$ concentrations investigated (i.e., from 0.025 to $0.25 \mathrm{M}$, see Fig. S3† higher concentrations of $\mathrm{Al}^{3+}$ were not examined because they lead to $\mathrm{pH}$ values below 3, which cannot easily be adjusted to higher values without aluminum salt precipitation).\& Such behavior strongly supports a reversible charging/discharging process that is rate-controlled by diffusional mass transport of aluminum ions in solution.

As illustrated with the chronoabsorptometry or galvanostatic experiments in Fig. 2, when enough time is given for the charge storage process to take place, the electrode absorbance reaches an equilibrium value that depends only on the applied potential (suggesting conditions entirely governed by thermodynamics).

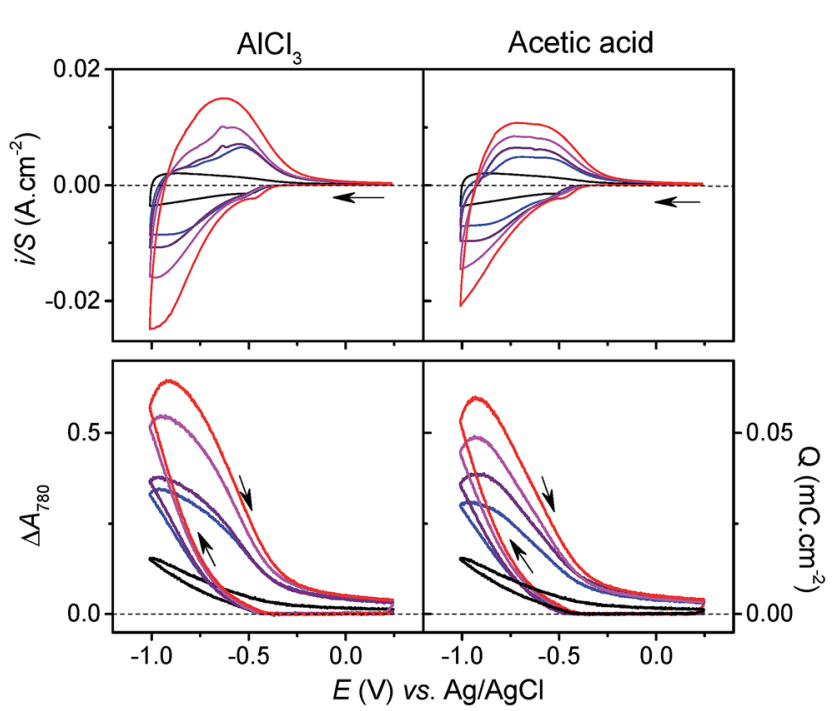

Fig. 3 Cyclic voltammograms (CVs) and cyclic voltabsorptograms (CVAs) recorded at a GLAD- $\mathrm{TiO}_{2} / \mathrm{TiO}_{2} / \mathrm{ITO}$ electrode in an aqueous solution (adjusted to $\mathrm{pH} 3.0$ ) containing $0.3 \mathrm{M} \mathrm{KCl}$ (except for the highest $\mathrm{AlCl}_{3}$ concentration) and increasing concentrations of (left) $\mathrm{AlCl}_{3}$ or (right) acetic acid. The $\mathrm{AlCl}_{3}$ or acetic acid concentrations were as follows: (black curves) $0 \mathrm{mM}$, (blue curves) $25 \mathrm{mM}$, (purple curves) $50 \mathrm{mM}$, (magenta curves) $100 \mathrm{mM}$, and (red curves) $250 \mathrm{mM}$. Scan rate: $0.1 \mathrm{~V} \mathrm{~s}^{-1}$. The black arrows indicate the potential scan direction.
From the magnitude of the equilibrium absorbance change (indicative of an equilibrium amount of electrons stored within the material) recorded here at $-0.82 \mathrm{~V}$, a gravimetric capacity of $65 \mathrm{~mA} \mathrm{~h} \mathrm{~g}^{-1}$ can be estimated, which is 5-fold more than in the absence of $\mathrm{AlCl}_{3}$ at the same $\mathrm{pH}$ and potential (i.e., $\sim 13 \mathrm{~mA} \mathrm{~h} \mathrm{~g}^{-1}$ ). Additionally, under the selected experimental conditions, the charging process is fully reversible as attested by the complete restoration of the initial absorbance. All of these observations clearly suggest the occurrence of a reversible faradaic process, rate-limited by a diffusional mass transport involving $\mathrm{Al}^{3+}$. These results also confirm what has previously been obtained by other groups (see Table 1). ${ }^{23,26-30,34}$

At first sight, it is tempting to attribute this reversible charging process to the reversible faradaic reduction of the $\mathrm{Ti}^{\mathrm{IV}}$ sites coupled with intercalation of $\mathrm{Al}^{3+}$ into $\mathrm{TiO}_{2}$ (to locally compensate the loss of charge within the metal oxide lattice) according to the following global reaction:

$$
\mathrm{TiO}_{2}+3 x \mathrm{e}^{-}+x \mathrm{Al}^{3+} \leftrightarrows \mathrm{Al}_{x} \mathrm{TiO}_{2}
$$

This reaction mechanism was proposed by several groups $^{23,26,28-30,34}$ (see Table 1), arguing that the small radius of $\mathrm{Al}^{3+}$ as compared to $\mathrm{Li}^{+}(0.053 \mathrm{~nm}$ vs. $0.069 \mathrm{~nm}$, see Table S1†) facilitates intercalation and migration within the solid phase of $\mathrm{TiO}_{2}$. On the basis of eqn (3), experimental $x$ values ranging from 0.076 to 0.27 were thus proposed, ${ }^{23,29}$ which for the highest values, is near the maximal theoretical value (i.e., 0.33) assuming that all the $\mathrm{Ti}^{\mathrm{IV}}$ atoms in $\mathrm{TiO}_{2}$ can be reduced into $\mathrm{Ti}^{\mathrm{III}}$ and that $3 \mathrm{Ti}^{\mathrm{III}}$ atoms are involved for each $\mathrm{Al}^{3+}$ ion inserted. This, however, does not take into consideration that dissolution of $\mathrm{Al}^{3+}$ salts in aqueous solutions leads to the formation of $\left[\mathrm{Al}\left(\mathrm{H}_{2} \mathrm{O}\right)_{6}\right]^{3+}$, a hexaaquo ion complex characterized by a rather large molecular size (diameter $>0.38 \mathrm{~nm}$ according to the $\mathrm{Al}-\mathrm{O}$ internuclear distance of $0.19 \mathrm{~nm}$ (ref. 50)), in which the coordinated water molecules are strongly bonded because of the high charge and small size of $\mathrm{Al}^{3+}\left(\Delta G_{\text {hydration }}^{0}=\right.$ $-4525 \mathrm{~kJ} \mathrm{~mol}^{-1}$, which is 10 -fold higher than $\left.\mathrm{Li}^{+}\right) .{ }^{35}$ Accordingly, insertion of the unsolvated $\mathrm{Al}^{3+}$ ion into $\mathrm{TiO}_{2}$ must be thermodynamically more difficult (i.e., shifted to more negative potentials) than insertion of a monovalent cation of similar size and lower solvation energy (for instance $\mathrm{Li}^{+}$). In other words, insertion of $\mathrm{Al}^{3+}$ into $\mathrm{TiO}_{2}$ is expected to be penalized by the high energy cost associated with desolvation of its hydration shell (corresponding to a high change in Gibbs free energy for the ion insertion potential, i.e. $\left.\Delta E_{\mathrm{i}}=-\Delta G_{\mathrm{i}} / n F\right)$. Additionally, as already mentioned in the introduction, the strong coulombic interaction that is presumed to occur between the highly charged $\mathrm{Al}^{3+}$ and the surrounding $\mathrm{TiO}_{2}$ lattice should strongly hinder the solid-state cation diffusion. ${ }^{36}$

An additional aspect that has not previously been sufficiently taken into account is the weak acidity of the $\left[\mathrm{Al}\left(\mathrm{H}_{2} \mathrm{O}\right)_{6}\right]^{3+}$ complex, resulting from the Lewis acidity of $\mathrm{Al}^{3+}$ that strongly polarizes the coordinated water molecules in the hexaaquo complex. This polarization is sufficient to make the hydrogen atoms of the bonded water molecules more acidic than normal water molecules. For this reason, the $\left[\mathrm{Al}\left(\mathrm{H}_{2} \mathrm{O}\right)_{6}\right]^{3+}$ complex is characterized by a weak Brønsted acidity of $\mathrm{p} K_{\mathrm{a}}=4.97 .^{51}$ 
Accordingly, the dissolution of $0.25 \mathrm{AlCl}_{3}$ in water leads to the following equilibrium mixture of ionic species in solution: $0.249 \mathrm{M}\left[\mathrm{Al}\left(\mathrm{H}_{2} \mathrm{O}\right)_{6}\right]^{3+}, 1 \mathrm{mM}\left[\mathrm{Al}\left(\mathrm{H}_{2} \mathrm{O}\right)_{6}(\mathrm{OH})\right]^{2+}, 1 \mathrm{mM} \mathrm{H}_{3} \mathrm{O}^{+}(\mathrm{pH}$ 3.0) and $0.75 \mathrm{M} \mathrm{Cl}^{-}$. The electrolyte therefore consists of a large amount of $\left[\mathrm{Al}\left(\mathrm{H}_{2} \mathrm{O}\right)_{6}\right]^{3+}$ which, due to its weakly acidic properties, can be considered as an abundant latent source of protons. This source is much more abundant than the free proton concentration, which at $\mathrm{pH} 3.0$ can be considered negligible. This means that the aluminum hexaaquo complex, rather than acting as an intercalating cation, can serve as a proton source to locally compensate the negative charge generated by reduction of $\mathrm{TiO}_{2}$, a process that can be formally described by the following interfacial reaction scheme:

$\mathrm{TiO}_{2}+x \mathrm{e}^{-}+x\left[\mathrm{Al}\left(\mathrm{H}_{2} \mathrm{O}\right)_{6}\right]^{3+} \leftrightarrows \mathrm{TiOOH}_{x}+x\left[\mathrm{Al}\left(\mathrm{H}_{2} \mathrm{O}\right)_{5}(\mathrm{OH})\right]^{2+}(4)$

This proposed mechanism is also based on our recent finding that a weak organic acid such as the conjugate acid form of the zwitterionic HEPES buffer (i.e., 4-(2-hydroxyethyl)-1piperazineethanesulfonate, $\left.\mathrm{p} K_{\mathrm{a}, 2}=7.5\right)$ can be an efficient proton donor to assist the proton insertion-coupled charge transfer generated at a negatively biased GLAD- $\mathrm{TiO}_{2}$ electrode in a neutral aqueous buffer ( $\mathrm{pH} 7.0) .{ }^{37}$ By extension, we can postulate that a similar charge storage mechanism is at work in the presence of an $\mathrm{Al}^{3+}$-based electrolyte, wherein $\left[\mathrm{Al}\left(\mathrm{H}_{2} \mathrm{O}\right)_{6}\right]^{3+}$ is recruited as a source of protons at the metal oxide/electrolyte interface to promote the insertion of protons within the metal oxide lattice.

The first item in favor of this proton insertion mechanism is the remarkably fast charging/discharging rate evidenced by: (i) the reversible wave in $\mathrm{CV}$, which remains particularly welldefined despite the unusually high scan rate used here $(v=$ $0.1 \mathrm{~V} \mathrm{~s}^{-1}$ in Fig. 2, which is much higher than that ordinarily used to characterize Li-ion insertion in $\left.\mathrm{TiO}_{2}\left(v<10 \mathrm{mV} \mathrm{s}{ }^{-1}\right)\right),{ }^{52}$ (ii) the chronoabsorptometry experiment of Fig. 2 which demonstrates rapid charging to a gravimetric capacity as high as $61 \mathrm{~mA} \mathrm{~h} \mathrm{~g}{ }^{-1}$ in less than $1 \mathrm{~min}$ at $-0.82 \mathrm{~V}$, (iii) the galvanostatic experiments at different rates in Fig. $\mathrm{S} 4 \uparrow$ from which remarkably high charging efficiencies could be estimated (i.e., values as high as $70 \%$ at $1.6 \mathrm{~A} \mathrm{~g}^{-1}$, i.e. $45 \mathrm{~mA} \mathrm{~h} \mathrm{~g}{ }^{-1}$ at $0.4 \mathrm{~mA}$ $\mathrm{cm}^{-2}$, or $40 \%$ at $8 \mathrm{~A} \mathrm{~g}^{-1}$, i.e. $27 \mathrm{~mA} \mathrm{~h} \mathrm{~g}^{-1}$ at $2 \mathrm{~mA} \mathrm{~cm}^{-2}$ at a cutoff potential of $-0.82 \mathrm{~V}) . \S$

This fast charging/discharging rate clearly supports fast uptake/release of the charge compensating cation. Uptake/ release is fast enough that charge/discharge is almost always fully controlled by the mass transport of $\left[\mathrm{Al}\left(\mathrm{H}_{2} \mathrm{O}\right)_{6}\right]^{3+}$ in solution (Fig. 3 and $\mathrm{S} 3 \dagger$ ), a behavior that is supported by the close-tolinear dependence of the peak current in $\mathrm{CV}$ as a function of $\left[\mathrm{AlCl}_{3}\right]$ (see Fig. S3 and its comment in ESI $\dagger$ ). This observation argues in favor of proton insertion rather than $\mathrm{Al}^{3+}$ intercalation, which considering the ionic size argument, makes sense because the ionic radius of a proton is $\sim 6 \times 10^{4}$-fold smaller than $\mathrm{Al}^{3+}$ (see Table $\mathrm{S} 1 \dagger$ ).

\subsection{Charge storage in the presence of $0.25 \mathrm{M}$ acetic acid, pH 3.0}

If we assume that, because of its weakly acidic character, $\left[\mathrm{Al}\left(\mathrm{H}_{2} \mathrm{O}\right)_{6}\right]^{3+}$ only acts as a donor to promote proton insertion at the $\mathrm{TiO}_{2} /$ electrolyte interface, then by extrapolation, we can expect that other weak acids could support the same $\mathrm{H}^{+}$insertion process. If this assumption is true, then it is reasonable to anticipate that under similar concentration and $\mathrm{pH}$ conditions, it should be impossible to differentiate the electrochemical experiments performed in an electrolyte containing $\left[\mathrm{Al}\left(\mathrm{H}_{2} \mathrm{O}\right)_{6}\right]^{3+}$ from those performed in an electrolyte containing an organic weak acid of similar $\mathrm{p} K_{\mathrm{a}}$. To test this hypothesis, the spectroelectrochemical experiments performed with $\mathrm{Al}^{3+}$ were repeated with acetic acid, a monoprotic organic acid having a $\mathrm{p} K_{\mathrm{a}}$ of 4.76 , almost identical to $\left[\mathrm{Al}\left(\mathrm{H}_{2} \mathrm{O}\right)_{6}\right]^{3+}\left(\mathrm{p} K_{\mathrm{a}}=4.97\right)$. To replicate the proton donor concentration and ionic strength of the $\mathrm{Al}^{3+}$-based experiments, an aqueous solution containing $0.25 \mathrm{M}$ acetic acid and $0.3 \mathrm{M} \mathrm{KCl}$, adjusted to $\mathrm{pH}$ 3.0, was used. The experimental data obtained with the acetic acid electrolyte at a GLAD-TiO $/ \mathrm{TiO}_{2} / \mathrm{ITO}$ electrode are reported in Fig. 2 and 3. Whatever the electrochemical technique used, it immediately emerges from Fig. 2 that the experimental data recorded in the presence of acetic acid are highly similar to those obtained in the $\mathrm{Al}^{3+}$-based electrolyte. In the presence of acetic acid, the CV and CVA show the appearance of an intense and broad reversible wave, whose shape, current intensity (or absorbance change), and potential positioning are almost overlaid with those obtained using the $\mathrm{Al}^{3+}$-based electrolyte. The absence of a potential shift in the position of the reversible wave is a strong indication that, thermodynamically, the same cationic species is involved in the faradaic transformation of $\mathrm{TiO}_{2}$. This observation is again consistent with proton insertion rather than $\mathrm{Al}^{3+}$ insertion (it is indeed hard to envision that the reducing potential of $\mathrm{TiO}_{2}$ does not depend on the nature of the inserted cation, a dependence that has been well-identified for the insertion of alkali-ions in solid metal hexacyanometalates and mainly attributed to a difference in the solvation energy of the cations ${ }^{53,54}$. Also, similar to the results found with $\mathrm{Al}^{3+}$, the magnitude of the reversible wave and absorbance change was observed to increase with the concentration of acetic acid (Fig. 3 and $\mathrm{S} 5 \dagger$ ), confirming that acetic acid is directly involved in the charge storage mechanism. Furthermore, once corrected for the contribution of the capacitive current, the magnitude of the cathodic and anodic peak currents in CV were observed to vary proportionally with $\sqrt{v}$ over the entire range of acetic acid concentrations investigated (Fig. $55 \dagger$ ).

Again, this behavior is analogous to that obtained with the $\mathrm{Al}^{3+}$-based electrolyte, clearly suggesting a faradaic charging mechanism rate-controlled by diffusional mass transport, which here can unambiguously be attributed to the mass transport of the acetic acid in solution.

Other striking similarities in Fig. 2 are the charging and discharging rates which, in light of the chronoamperometry or chronoabsorptometry experiments, lead to almost identical kinetic traces for the two electrolytes. This is also the case for the galvanostatic experiments, which show very similar charging/discharging curves in each electrolyte. Additionally, the maximal equilibrium amount of charge reached at the end of the chronoamperometric or chronoabsorptometric experiments (i.e., at $-0.82 \mathrm{~V}$ ) are the same in both electrolytes (i.e., 67$68 \mathrm{~mA} \mathrm{~h} \mathrm{~g}{ }^{-1}$ ). The similarities in the charging/discharging rates 
and in the amounts of accumulated charge with both electrolytes strongly suggest that the same cationic species is involved in the charge storage mechanism, and that the cation common to the two electrolytes is the proton, not $\mathrm{Al}^{3+}$.

Because of their much higher stability under strongly reducing conditions, we examined the influence of an increasingly negative cut-off potential (ranging from $-0.82 \mathrm{~V}$ up to -1.12 $\mathrm{V})$ on the galvanostatic charging of GLAD-TiO ${ }_{2} / \mathrm{Ti}$ electrodes. This was done both in the presence and the absence of a proton donor. The resulting galvanostatic charging/discharging curves reported in Fig. 4 show that in the presence of $\mathrm{AlCl}_{3}$ or acetic acid, the amount of charge reversibly stored in the mesoporous film at a charging rate of $1.6 \mathrm{~A} \mathrm{~g}^{-1}$ is steadily increased as the negative cut-off potential is progressively shifted to more negative values, reaching a gravimetric capacity as high as $115 \mathrm{~mA} \mathrm{~h} \mathrm{~g}^{-1}$ at the most negative cut-off potential of $-1.12 \mathrm{~V}$ in both electrolytes. 9 The main factor that impedes a more extensive reduction of the GLAD-TiO ${ }_{2}$ film is the competitive hydrogen evolution reaction that becomes progressively more dominant with application of increasingly negative potentials (and which leads to the obvious release of dihydrogen bubbles at the electrode interface). This is well-evidenced in Fig. 4 through the charge storage coulombic efficiency which decreases as the cut-off potential is raised to more negative values.

Despite the competitive hydrogen evolution, we found that the reversible gravimetric capacity could be improved to $155 \mathrm{~mA} \mathrm{~h} \mathrm{~g}^{-1}$ at a GLAD-TiO $/$ /Ti electrode by further increasing the acetic acid-based electrolyte concentration to $8 \mathrm{M}$ (Fig. S6 $\dagger$ ). This charge storage capacity is not far from the maximal theoretical value of $167 \mathrm{~mA} \mathrm{~h} \mathrm{~g}^{-1}$ assuming by analogy to $\mathrm{Li}^{+}, 55$ that only half of the bulk $\mathrm{Ti}^{\mathrm{IV}}$ sites in $\mathrm{TiO}_{2}$ can be reduced into $\mathrm{Ti}^{\mathrm{III}}$ $(x=0.5)$.
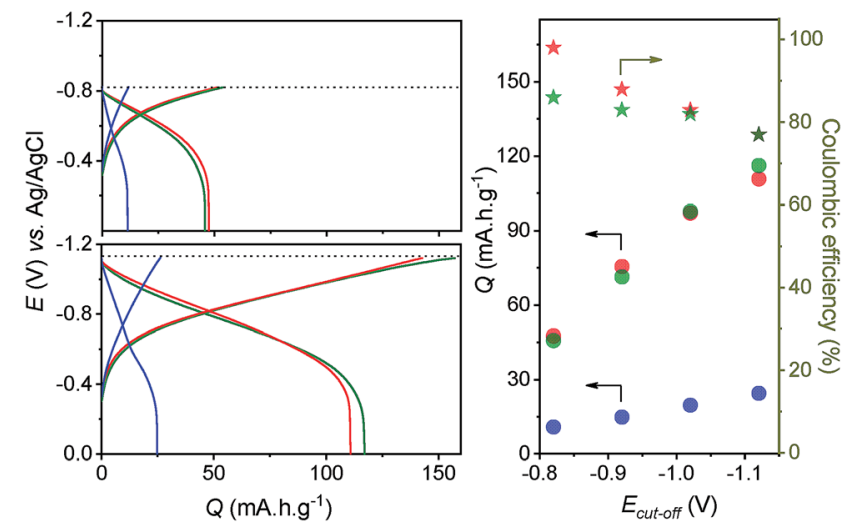

Fig. 4 (Left) Galvanostatic charging and discharging curves recorded at $1.6 \mathrm{~A} \mathrm{~g}^{-1}$ at $\mathrm{GLAD}-\mathrm{TiO}_{2} / \mathrm{Ti}$ electrodes in aqueous electrolytes (adjusted to $\mathrm{pH} 3.0$ ) containing (blue) $0.3 \mathrm{M} \mathrm{KCl}$, (green) $0.25 \mathrm{M}$ acetic acid and $0.3 \mathrm{M} \mathrm{KCl}$, or (red) $0.25 \mathrm{M} \mathrm{AlCl}_{3}$. The negative cut-off potential (dotted line) was fixed to (top) $-0.82 \mathrm{~V}$ or (bottom) $-1.12 \mathrm{~V}$. (Right) (dot symbols) Reversible charge storage capacities $(Q)$ and (start symbols) coulombic efficiencies (all recovered from galvanostatic experiments performed at $1.6 \mathrm{~A} \mathrm{~g}^{-1}$ ) plotted as a function of the negative cut-off potential. The code color is the same than on the left graph, referring to the electrolyte composition.

\subsection{Interpretation in terms of proton-coupled electron storage}

As acetic acid cannot itself insert within the $\mathrm{TiO}_{2}$ structure, and the free proton concentration at $\mathrm{pH} 3.0$ is quite low, the only way to explain the faradaic response observed in the presence of this weak acid is that the latter behaves as a proton donor (i.e., a Brønsted weak acid, $\mathrm{AH}$ ) at the $\mathrm{TiO}_{2}$ interface, exactly as we have previously shown at neutral $\mathrm{pH}$ with the HEPES buffer. ${ }^{37,56}$ This type of proton-coupled electron charge storage can be formally expressed as follows:

$$
\mathrm{TiO}_{2}+x \mathrm{e}^{-}+x \mathrm{AH} \leftrightarrows \mathrm{TiOOH}_{x}+x \mathrm{~A}^{-}
$$

where $\mathrm{AH}$ is the weak acid (here the acetic acid) and $\mathrm{A}^{-}$its conjugate base. Also, as we have previously shown, ${ }^{37,56}$ this global reaction can be more accurately described by the following reaction mechanism:

$$
\begin{gathered}
\mathrm{Ti}^{\mathrm{IV}} \mathrm{O}_{2}+\mathrm{e}^{-}+\mathrm{AH} \leftrightarrows \mathrm{Ti}^{\mathrm{III}}(\mathrm{O})(\mathrm{OH})+\mathrm{A}^{-} \\
\mathrm{Ti}^{\mathrm{IV}} \mathrm{O}_{2}+\mathrm{Ti}^{\mathrm{III}}(\mathrm{O})(\mathrm{OH}) \leftrightarrows \mathrm{Ti}^{\mathrm{III}}(\mathrm{O})(\mathrm{OH})+\mathrm{Ti}^{\mathrm{IV}} \mathrm{O}_{2}
\end{gathered}
$$

wherein the first step corresponds to interfacial proton-coupled electron transfer at the metal oxide/electrolyte interface, and the second step to solid-state proton migration/diffusion within the metal oxide lattice (see the illustrative cartoon in Fig. 1). An additional step that is not explicitly formulated here is the diffusional mass transport of $\mathrm{AH}$ in solution and which, under insufficiently high concentration of proton donor, can be rate limiting. As we have demonstrated in our previous work, ${ }^{37,56}$ depending on the experimental conditions, the charging/ discharging process at a GLAD $\mathrm{TiO}_{2}$ electrode can be exclusively rate-limited by one of the aforementioned kinetic processes or by a mixed control of any combination. ${ }^{56}$ If we assume a fast interfacial proton-coupled electron transfer, which is reasonable on account of the relatively well-defined reversible peaks we observed in the $\mathrm{CV}$ at unconventionally fast scan rates, it becomes possible to experimentally extract some pertinent kinetic parameters. We consider the transition from one limiting case where the charge storage kinetics are entirely governed by diffusion of the proton donor in solution to another limiting case where the process is solely rate-limited by solid-state diffusion of protons within the $\mathrm{TiO}_{2}$ bulk lattice. This transition can be revealed by recording the diffusion controlled cathodic or anodic peak currents in $\mathrm{CV}$ as a function of the $\mathrm{AH}$ concentration, as shown in Fig. 5. Whatever the nature of the electrolyte, a linear relationship is observed in Fig. 5 (see the inset) at low $\mathrm{AH}$ concentrations $([\mathrm{AH}] \leq 0.1 \mathrm{M})$, characteristic of a charge storage mechanism rate-limited by the diffusional mass transport of either the acetic acid or $\left[\mathrm{Al}\left(\mathrm{H}_{2} \mathrm{O}\right)_{6}\right]^{3+}$ in the electrolyte. Under these conditions, the solution diffusion coefficient of AH can be directly extracted from the slope of the linear part (or tangent) of the experimental data using the following modified Randles-Sevcik equation: ${ }^{56}$

$$
\frac{i_{\mathrm{p}}}{S}=0.419 F[\mathrm{AH}] \sqrt{D_{\mathrm{AH}}} \sqrt{\frac{F v}{R T}}
$$




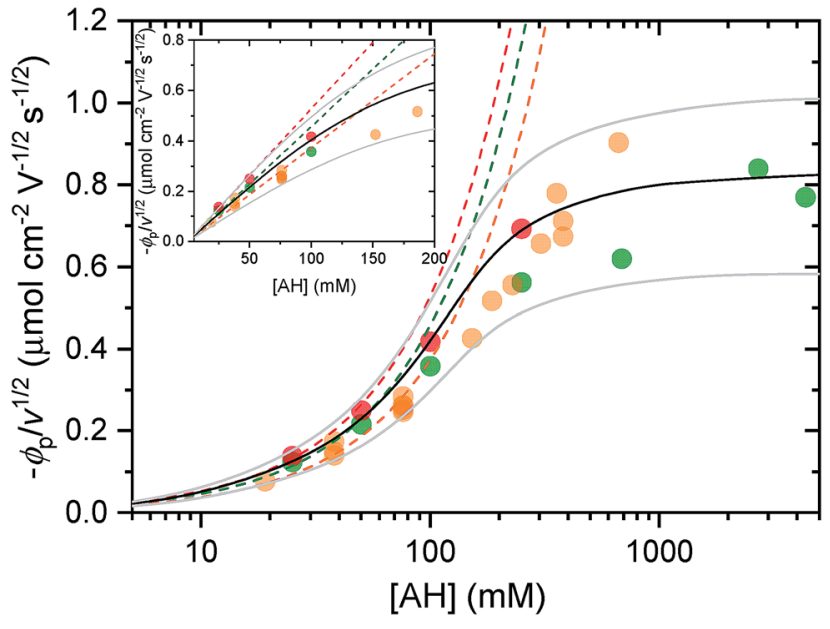

Fig. 5 Cathodic peak potential (expressed in flux density and normalized to $v^{1 / 2}$ ) as a function of $\mathrm{AH}$ concentration in the electrolyte (adjusted to $\mathrm{pH} 3.0$ ), where $\mathrm{AH}$ is (red) $\left[\mathrm{Al}\left(\mathrm{H}_{2} \mathrm{O}\right)_{6}\right]^{3+}$, (green) acetic acid, and (orange) the weak acid conjugate of the HEPES buffer. The dashed lines correspond to the linear regression fits of eqn (8) to the low concentration range of the experimental data, from which the following diffusion coefficients of the proton donor in solution, i.e. $D_{\mathrm{AH}}$, were recovered: (red) $4 \times 10^{-6} \mathrm{~cm}^{2} \mathrm{~s}^{-1}$, (green) $3 \times 10^{-6} \mathrm{~cm}^{2} \mathrm{~s}^{-1}$, and (orange) $2 \times 10^{-6} \mathrm{~cm}^{2} \mathrm{~s}^{-1}$. HEPES data ( $\mathrm{pH}$ 7.0) are reproduced from (ref. 37). The black and gray plain lines are the numerical simulations of the model reported in (ref. 56) using a $D_{A H}$ value of $(3 \pm 1.5) \times$ $10^{-6} \mathrm{~cm}^{2} \mathrm{~s}^{-1}$ and a solid-state diffusion coefficient of $(5 \pm 2.5) \times 10^{-16}$ $\mathrm{cm}^{2} \mathrm{~s}^{-1}$. The grey simulated curves that bookend the black have been calculated by taking into account the confidence range on the diffusion coefficients. Inset: magnification of the lower concentration range (linear scale).

where $i_{\mathrm{p}}$ is the cathodic peak current (in A), $S$ the delimited geometric electrode area (in $\mathrm{cm}^{2}$ ), $[\mathrm{AH}]$ the concentration of proton donor in the aqueous electrolyte (in $\mathrm{mol} \mathrm{cm}^{-3}$ ), $D_{\mathrm{AH}}$ the diffusion coefficient of $\mathrm{AH}$ in solution (in $\mathrm{cm}^{2} \mathrm{~s}^{-1}$ ), and $v$ the scan rate (in $\mathrm{V} \mathrm{s}^{-1}$ ). From the best curve fittings in Fig. 5 (dashed straight lines), values of $4 \times 10^{-6} \mathrm{~cm}^{2} \mathrm{~s}^{-1}$ and $3 \times 10^{-6} \mathrm{~cm}^{2} \mathrm{~s}^{-1}$ were recovered for $\left[\mathrm{Al}\left(\mathrm{H}_{2} \mathrm{O}\right)_{6}\right]^{3+}$ and acetic acid, respectively. These values are in the range of those reported in the literature, i.e. $5.4 \times 10^{-6} \mathrm{~cm}^{2} \mathrm{~s}^{-1}$ for aqueous $\mathrm{Al}^{3+}$ and $1.3 \times 10^{-5} \mathrm{~cm}^{2} \mathrm{~s}^{-1}$ for the acetic acid..$^{57}$ The data we had previously obtained ${ }^{37}$ in a neutral HEPES buffer ( $\mathrm{pH}$ 7.0) were also added to Fig. 5. Comparison of data obtained in a HEPES buffer with those recovered in $\mathrm{Al}^{3+}$-based or acetic acid-based electrolytes shows similar trends with a near overlay of the data over the entire range of proton donor concentrations. Both trends also include progressive deviations from linearity at higher AH concentrations, which is characteristic of transition to kinetic control by the solid-state diffusion of the inserted cation. Although it was not possible to further increase the $\mathrm{AlCl}_{3}$ concentration (because of both $\mathrm{pH}$ considerations and competitive proton insertion arising from the free protons in solution) to make the peak current fully independent of the $\mathrm{AH}$ concentration, we assessed this limiting case from numerical simulations of the model we have previously proposed. ${ }^{56}$ The numerically calculated plots that best fit the experimental data are given in Fig. 5 (black and grey curves). These plots were obtained by employing an average value for the diffusion coefficient of the various proton donors in solution (i.e., $\left.D_{\mathrm{AH}}=(3 \pm 1.5) \times 10^{-6} \mathrm{~cm}^{2} \mathrm{~s}^{-1}\right)$, and by adjusting the value of the solid-state diffusion coefficient within a certain range reflecting the scatter in the experimental data. Considering all of the data obtained for the different electrolytes, the diffusion coefficients converged to a single average value of $(5 \pm 2.5) \times 10^{-16} \mathrm{~cm}^{2} \mathrm{~s}^{-1}$. This convergence to a single solid-state diffusion coefficient is once again a strong argument in favor of a consistent cationic species that inserts into $\mathrm{TiO}_{2}$, and this species cannot be other than the proton.

\subsection{Extension to other multivalent metallic ions}

If $\left[\mathrm{Al}\left(\mathrm{H}_{2} \mathrm{O}\right)_{6}\right]^{3+}$ serves as an efficient proton source due to its Brønsted acidity, one can presume that this effect can also extend to other multivalent hexaaquo metal ions exhibiting weak acid properties in aqueous solution. ${ }^{51}$ We have thus investigated the electrochemical charging of GLAD $\mathrm{TiO}_{2} / \mathrm{TiO}_{2} /$ ITO electrodes in aqueous electrolytes (adjusted to $\mathrm{pH}$ 3.0) containing either $0.25 \mathrm{M} \mathrm{ZnCl}_{2}$ or $0.25 \mathrm{M} \mathrm{MnCl}_{2}$, two divalent metal ions that are commonly present in a wide range of aqueous zinc-ion batteries. ${ }^{\mathbf{1 , 3 , 7 , 9 - 1 1}}$ As for $\mathrm{AlCl}_{3}$, once $\mathrm{ZnCl}_{2}$ and $\mathrm{MnCl}_{2}$ are dissolved in aqueous solution, they form hexaaquo complexes $\left[\mathrm{Zn}\left(\mathrm{H}_{2} \mathrm{O}\right)_{6}\right]^{2+}$ and $\left[\mathrm{Mn}\left(\mathrm{H}_{2} \mathrm{O}\right)_{6}\right]^{2+}$, characterized by $\mathrm{p} K_{\mathrm{a}}$ values of 9.0 and 10.6, respectively (Table S1†). The resulting CVs and CVAs reported in Fig. 6 show a net increase in current density and absorbance change (monitored at $780 \mathrm{~nm}$ ) at potentials lower than $-0.5 \mathrm{~V}$ as compared to the same electrode scanned in a pure $0.3 \mathrm{M} \mathrm{KCl}$ electrolyte. Also similar to $\left[\mathrm{Al}\left(\mathrm{H}_{2} \mathrm{O}\right)_{6}\right]^{3+}$, this increase is proportional to $v^{1 / 2}$ and a function of the metal ion concentration in solution, behaviors which attest to a charge storage process kinetically governed by the solution mass transport of metal ions toward the electrode surface. It is interesting to note that $\mathrm{Zn}^{2+}$ and $\mathrm{Mn}^{2+}$ have much larger ionic radii than $\mathrm{Li}^{+}$and $\mathrm{Al}^{3+}$ (see Table $\mathrm{S} 1 \dagger$ ), so that the cation size argument can no longer explain the increase of capacity by uptake of these divalents ions within the $3 \mathrm{D}$ structure of $\mathrm{TiO}_{2}$. Hence, the increase of capacity can again be unambiguously attributed to the reversible insertion of protons provided by the hexaaquo metal ion complexes during the reversible reduction of $\mathrm{TiO}_{2}$.

The main difference that become apparent in side-by-side comparison of the CVs and CVAs recorded in the various electrolytes is the somewhat lower charging/discharging current densities and absorbance changes when using $\left[\mathrm{Zn}\left(\mathrm{H}_{2} \mathrm{O}\right)_{6}\right]^{2+}$ and $\left[\mathrm{Mn}\left(\mathrm{H}_{2} \mathrm{O}\right)_{6}\right]^{2+}$, indicating a lower charge storage efficiency with these metal ions as compared to $\left[\mathrm{Al}\left(\mathrm{H}_{2} \mathrm{O}\right)_{6}\right]^{3+}$. We attribute this effect to the lower Brønsted acidity of $\left[\mathrm{Zn}\left(\mathrm{H}_{2} \mathrm{O}\right)_{6}\right]^{2+}$ and $\left[\mathrm{Mn}\left(\mathrm{H}_{2} \mathrm{O}\right)_{6}\right]^{2+}$, which indicates that protons are donated less easily than the aluminum complex. This effect is also most likely accompanied by a shift of the reversible proton-insertion wave to more negative potentials, which makes sense if we consider the higher energetic cost required to dissociate the acidic proton from $\left[\mathrm{Zn}\left(\mathrm{H}_{2} \mathrm{O}\right)_{6}\right]^{2+}$ and $\left[\mathrm{Mn}\left(\mathrm{H}_{2} \mathrm{O}\right)_{6}\right]^{2+}$ as compared to $\left[\mathrm{Al}\left(\mathrm{H}_{2} \mathrm{O}\right)_{6}\right]^{3+}$ (suggesting that the $\mathrm{p} K_{\mathrm{a}}$ of the proton donor is involved in the thermodynamics of the reversible proton- 

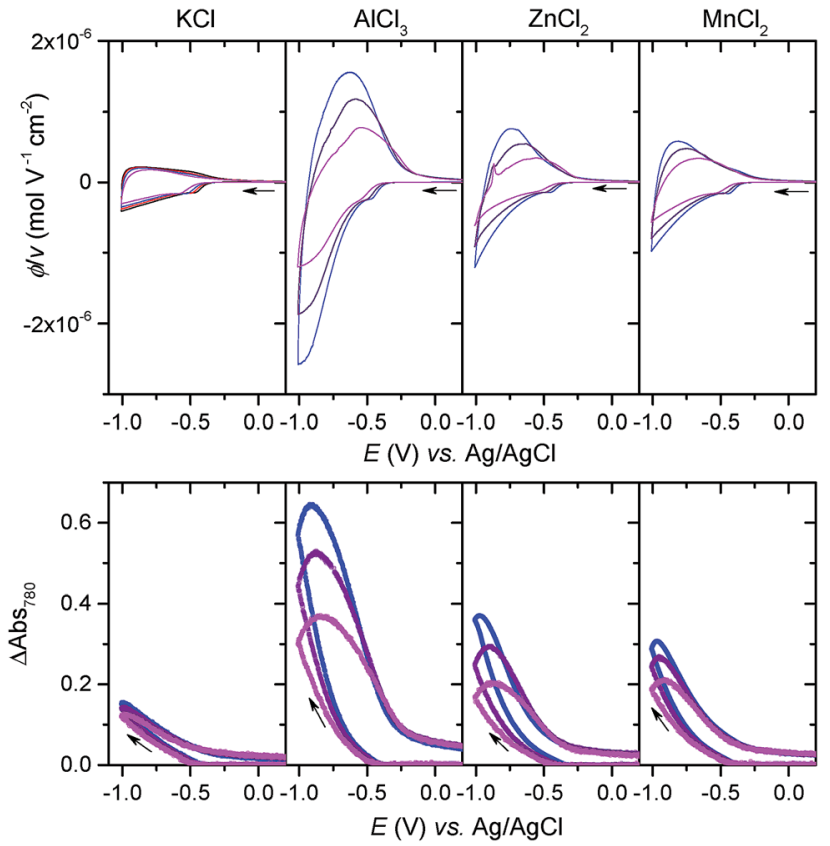

Fig. 6 (Top) Cyclic voltammograms and (Bottom) cyclic voltabsorptograms (monitored at $780 \mathrm{~nm}$ ) at a $\mathrm{GLAD}-\mathrm{TiO}_{2} / \mathrm{TiO}_{2} / \mathrm{ITO}$ electrode immersed in different aqueous electrolytes (adjusted to $\mathrm{pH}$ 3.0) made of (from left to right): $0.3 \mathrm{M} \mathrm{KCl}, 0.25 \mathrm{M} \mathrm{AlCl}_{3}, 0.25 \mathrm{M} \mathrm{ZnCl}_{2}$, or $0.25 \mathrm{M}$ $\mathrm{MnCl}_{2}$. Currents are expressed in flux density normalized to the scan rate. Scan rates: (blue) 0.1 , (purple) 0.2 , and (magenta) $0.5 \mathrm{~V} \mathrm{~s}^{-1}$. The potential is quoted vs. $\mathrm{Ag} / \mathrm{AgCl}$.

insertion process). In an attempt to better resolve the reversible proton-insertion wave in $\mathrm{CV}$ for each of the metal ions and to assess their formal potentials, we attempted to push the CV scans to more negative potentials. Unfortunately, these experiments were unsuccessful due to both the interference of hydrogen evolution and recurrent electrode failures at excessively negative potentials.

In order to better compare the equilibrium amount of charge that can be stored at $\mathrm{pH} 3.0$ within $\mathrm{GLAD}-\mathrm{TiO}_{2} / \mathrm{TiO}_{2} / \mathrm{ITO}$ electrodes as a function of the chemical nature of the electrolyte, potential step chronoabsorptometric experiments were performed by applying a charging potential (i.e., $-0.82 \mathrm{~V}$ ) close to the formal potential of the reversible proton insertion wave measured for acetic acid- and $\mathrm{Al}^{3+}$-based electrolytes (Fig. 7). After less than 2 min of charging, an almost constant absorbance value was systematically attained for all of the electrolytes but with different magnitudes, indicative of different charging equilibria. In the presence of $\mathrm{Zn}^{2+}$ - and $\mathrm{Mn}^{2+}$-based electrolytes, the absorbance increase at $780 \mathrm{~nm}$ is equivalent to a charge storage of $\sim 25 \mathrm{~mA} \mathrm{~h} \mathrm{~g}{ }^{-1}$, a value which is significantly higher than that obtained in a pure aqueous $\mathrm{KCl}$ electrolyte at the same $\mathrm{pH}$ (i.e. $13 \mathrm{~mA} \mathrm{~h} \mathrm{~g}^{-1}$ ). Even if this increase of capacity remains lower than with the acetic acid- or $\mathrm{Al}^{3+}$-based electrolytes, it demonstrates the advantageous effect of these metal ion electrolytes on proton-insertion charge storage. This effect was also observed to depend on $\mathrm{pH}$ as illustrated by the chronoabsorptometric experiments repeated for the same electrolytes at pH 5.0 and at an applied potential adjusted to $-0.94 \mathrm{~V}$

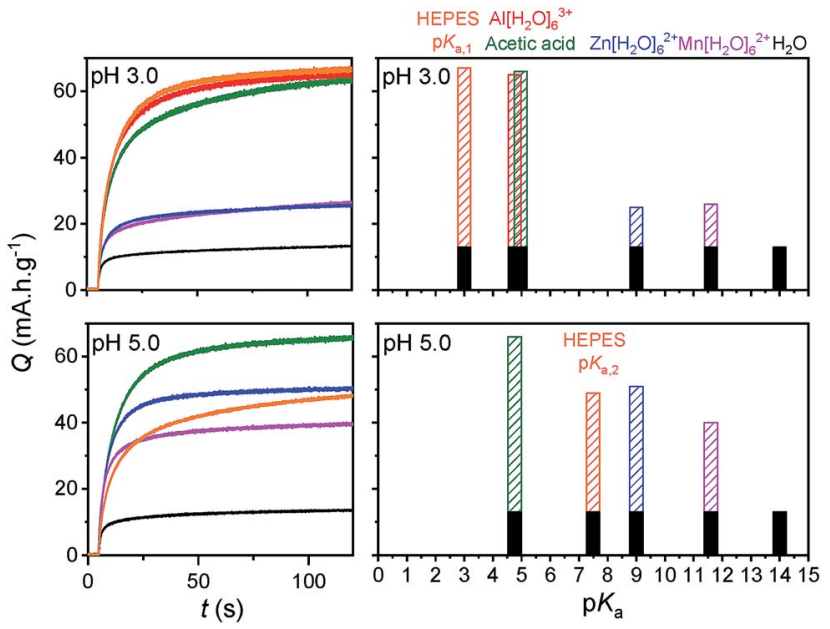

Fig. 7 (Left) Charge stored over the time course of reductive potential step chronoabsorptometry experiments performed at $\mathrm{GLAD}-\mathrm{TiO}_{2} /$ $\mathrm{TiO}_{2} / \mathrm{ITO}$ electrodes in different aqueous electrolytes adjusted to $\mathrm{pH}$ 3.0 or 5.0 (the $\mathrm{pH}$ values are reported on the graphs): (black) $0.3 \mathrm{M} \mathrm{KCl}$, (blue) $0.25 \mathrm{M} \mathrm{ZnCl}_{2}$, (magenta) $0.25 \mathrm{M} \mathrm{MnCl}_{2}$, (red) $0.25 \mathrm{M} \mathrm{AlCl}_{3}$, (green) $0.3 \mathrm{M} \mathrm{KCl}+0.25 \mathrm{M}$ acetic acid, and (orange) $0.3 \mathrm{M} \mathrm{KCl}+0.25 \mathrm{M}$ HEPES. The applied potential during the experiments was $-0.82 \mathrm{~V}$ at $\mathrm{pH} 3.0$ and $-0.94 \mathrm{~V}$ at pH 5.0 (vs. Ag/AgCl). (Right) Maximal charge stored as a function of $\mathrm{pH}$ and $\mathrm{p} K_{\mathrm{a}}$ of the proton donor. The black dense bar areas correspond to the charge stored at the electrical double layer (recovered from the experiment conducted in a $0.3 \mathrm{M} \mathrm{KCl}$ aqueous electrolyte), while the dashed areas correspond to the equilibrium charge stored through the faradaic reduction of $\mathrm{TiO}_{2}$ coupled to proton-ion insertion.

(Fig. 7) (the potential was adjusted to a $120 \mathrm{mV}$ more negative value in order to take into account the $-60 \mathrm{mV}$ shift of the conduction band potential per unit of $\mathrm{pH},{ }^{37}$ and through this to have comparable equilibrium charge storage conditions as at $\mathrm{pH}$ 3.0). This is particularly true for the weak acid $\left[\mathrm{Zn}\left(\mathrm{H}_{2} \mathrm{O}\right)_{6}\right]^{2+}$ and $\left[\mathrm{Mn}\left(\mathrm{H}_{2} \mathrm{O}\right)_{6}\right]^{2+}$ complexes which upon increasing the $\mathrm{pH}$ from 3.0 to 5.0 show a net gain in proton storage capacity. This, however, is not the case with acetic acid which remains nearly unchanged whatever the $\mathrm{pH}$. Independent of the proton storage capacities, the gravimetric capacities at $\mathrm{pH}$ 5.0 rapidly reach equilibrium whatever the nature of the electrolyte, and this proceeds with kinetics similar to those at $\mathrm{pH}$ 3.0.

In Fig. 7, the results of earlier studies in HEPES buffer adjusted to either $\mathrm{pH} 3.0$ or 5.0 were also added. The peculiarity of HEPES is its weak acidity characterized by two $\mathrm{p} K_{\mathrm{a}}$ values (i.e., $\mathrm{p} K_{\mathrm{a}, 1}=3.0$ and $\mathrm{p} K_{\mathrm{a}, 2}=7.5$ ). At $\mathrm{pH} 3.0$, the diprotic acidic form of HEPES is predominantly involved as a proton donor, while at pH 5.0 the less acidic zwitterionic form of HEPES dominates the proton charge storage.

The equilibrium amounts of charge reversibly stored either at pH 3.0 and 5.0 were plotted for each electrolyte as a function of the $\mathrm{p} K_{\mathrm{a}}$ of the proton donor in solution (Fig. 7). We also added water to the plot (i.e., the $\mathrm{H}_{2} \mathrm{O} / \mathrm{OH}^{-}$couple with a $\mathrm{p} K_{\mathrm{a}}$ value of 14 ) because of its potential involvement as a proton donor, although this effect is more likely to be observed in a pure $\mathrm{KCl}$ electrolyte under our experimental conditions. The results gathered in Fig. 7 clearly demonstrate that the proton storage efficiency at GLAD- 
$\mathrm{TiO}_{2}$ films strongly depends on both the $\mathrm{pH}$ of the electrolyte and the $\mathrm{p} K_{\mathrm{a}}$ of the proton donor. In agreement with our previous finding, ${ }^{37}$ water is inefficient in delivering protons under the present experimental conditions (aqueous $\mathrm{KCl}$ electrolyte of $\mathrm{pH}$ 3.0 or 5.0 ) and this is in spite of its very high concentration (i.e. $\sim 55 \mathrm{M}$ ). This behavior is clearly related to the low acidity of water $\left(\mathrm{p} K_{\mathrm{a}}=14\right)$. Likewise, at $\mathrm{pH} 3.0$, the lower efficiency of $\mathrm{Zn}^{2+}$ - and $\mathrm{Mn}^{2+}$-based electrolytes as compared to $\mathrm{Al}^{3+}$, acetic acid or HEPES can also be attributed to the lower acidity (or higher $\mathrm{p} K_{\mathrm{a}}$ values) of $\left[\mathrm{Zn}\left(\mathrm{H}_{2} \mathrm{O}\right)_{6}\right]^{2+}$ and $\left[\mathrm{Mn}\left(\mathrm{H}_{2} \mathrm{O}\right)_{6}\right]^{2+}$ relative to $\left[\mathrm{Al}\left(\mathrm{H}_{2} \mathrm{O}\right)_{6}\right]^{3+}$, acetic acid or HEPES. This effect is partially countered upon raising the $\mathrm{pH}$ to 5.0, wherein the weak acids $\left[\mathrm{Zn}\left(\mathrm{H}_{2} \mathrm{O}\right)_{6}\right]^{2+}$ and $\left[\mathrm{Mn}\left(\mathrm{H}_{2} \mathrm{O}\right)_{6}\right]^{2+}$ complexes become more efficient proton donors, but at the expense of a more negative applied potential value (or higher energy) than at $\mathrm{pH}$ 3.0.

\subsection{Comments on the discharging mechanism}

It is interesting to note that if we compare the discharging process to the charging process in chronopotentiometric experiments (Fig. 2), the former clearly appears to be much faster than the latter. This is a behavior we observed whatever the nature of the electrolyte. While a thermodynamic equilibrium is typically reached within $\sim 60 \mathrm{~s}$ of application of a reductive potential close to the formal potential of the reversible proton insertion $\left(E<E_{\mathrm{CB}}\right)$, the subsequent discharge of the electrode upon applying a positive bias $\left(E \gg E_{\mathrm{CB}}\right)$ occurs within a significantly shorter time, i.e. $<10 \mathrm{~s}$. If we assume that eqn (4) is a fully reversible process at the microscopic level, then one would assume that the discharging process also depends on the amount of conjugate base available at the metal oxide/ electrolyte interface. Since the present experiments were all performed at $\mathrm{pH} \ll \mathrm{p} K_{\mathrm{a}}$, the amount of base is low relative to the weak acid. The discharging process should thus be a priori slower than the charging process, however, this is not what we observed. This behavior thus raises fundamental questions on the mechanism of proton disinsertion from $\mathrm{TiO}_{2}$ that will be addressed in future work.

\section{Conclusions}

By comparing the electrochemical reversible charge storage at model GLAD- $\mathrm{TiO}_{2}$ electrodes in mild aqueous electrolytes containing either $\mathrm{AlCl}_{3}$ or acetic acid, we demonstrate that an identical faradaic charge storage mechanism occurs in both electrolytes. Contrary to the general belief that $\mathrm{Al}^{3+}$ ions insert within $\mathrm{TiO}_{2}$, we reveal rather that its hexaaquo ion complex acts as a proton donor at the $\mathrm{TiO}_{2} /$ electrolyte interface, similar to acetic acid. This allows for fast and massive proton-coupled electron storage even under conditions with a negligible concentration of free protons. These results are of great significance because the role of proton donor played by metal aquo complexes on the charge/discharge of $\mathrm{TiO}_{2}$ in an aqueous electrolyte can a priori extend to many other metal oxide electrode materials immersed either in aqueous electrolytes containing multivalent metal ions or in organic electrolytes containing multivalent metal ions and a small amount of water.
Additionally, the present results shed new light on mechanisms that may lead to systematically improved battery performances (i.e., higher gravimetric capacities as well as better rates) when the so-called rechargeable multivalent ion-insertion batteries operate in aqueous electrolytes ${ }^{7-13}$ rather than in a water-free organic electrolyte. ${ }^{\mathbf{1 4 , 1 6 , 1 8 - 2 0}}$

\section{Conflicts of interest}

The authors declare no conflicts of interest.

\section{Acknowledgements}

K. D. H. thanks Jeremy Sit for access to the GLAD evaporator, and the NRC Nanotechnology Initiative GIANNT project for partial funding support.

\section{Notes and references}

\$ The problem of working at a $\mathrm{pH}$ well below 3.0 is that the concentration of free protons becomes high enough to contribute significantly to charge storage via proton insertion, which therefore makes it more difficult to properly interpret the results we observed with the aluminum ion.

$\S$ Similar results were also obtained with the $\mathrm{GLAD}^{-} \mathrm{TiO}_{2} / \mathrm{Ti}$ electrodes under the same experimental conditions, confirming that the mesoporous $\mathrm{TiO}_{2}$ films behave similarly whether the GLAD $\mathrm{TiO}_{2}$ film has been deposited over an underlying ITO or Ti conductive substrate.

I It is important to note that this gravimetric capacity also includes the charges stored in the double layer capacitance of the high-surface area $\mathrm{TiO}_{2}$ film, which as shown in Fig. 4 corresponds to $25 \mathrm{~mA} \mathrm{~h} \mathrm{~g}^{-1}$ at $-1.12 \mathrm{~V}$ in the absence of a proton donor (i.e., in a pure $\mathrm{KCl}$ electrolyte). Accordingly, the capacity of the electrode resulting exclusively from the bulk faradaic reduction of $\mathrm{Ti}^{\mathrm{IV}}$ into $\mathrm{Ti}^{\mathrm{III}}$ can be estimated to be $90 \mathrm{~mA} \mathrm{~h} \mathrm{~g}^{-1}$ when working in acetic acid-based or $\mathrm{Al}^{3+}$-based electrolytes. This corresponds to the reduction of $\sim 27 \%$ of the total amount of $\mathrm{Ti}^{\mathrm{IV}}$ sites present in the mesoporous $\mathrm{TiO}_{2}$ film (i.e. $3.13 \times 10^{-6} \mathrm{~mol} \mathrm{~cm}{ }^{-2}$ estimated from the film density of $2.5 \mathrm{~g} \mathrm{~cm}^{-3}$ and a film thickness of $\left.1 \mu \mathrm{m}\right)$.

1 R. Guduru and J. Icaza, Nanomaterials, 2016, 6, 41.

2 P. Canepa, G. Sai Gautam, D. C. Hannah, R. Malik, M. Liu, K. G. Gallagher, K. A. Persson and G. Ceder, Chem. Rev., 2017, 117, 4287-4341.

3 Z. Xing, S. Wang, A. Yu and Z. Chen, Nano Energy, 2018, 50, 229-244.

4 V. Verma, S. Kumar, W. Manalastas, R. Satish and M. Srinivasan, Adv. Sustainable Syst., 2018, 3, 1800111.

5 Z. Chang, Y. Yang, M. Li, X. Wang and Y. Wu, J. Mater. Chem. A, 2014, 2, 10739-10755.

6 J. Liu, C. Xu, Z. Chen, S. Ni and Z. X. Shen, Green Energy \& Environment, 2018, 3, 20-41.

7 H. Pan, Y. Shao, P. Yan, Y. Cheng, K. S. Han, Z. Nie, C. Wang, J. Yang, X. Li, P. Bhattacharya, K. T. Mueller and J. Liu, Nat. Energy, 2016, 1, 16039.

8 D. Kundu, B. D. Adams, V. Duffort, S. H. Vajargah and L. F. Nazar, Nat. Energy, 2016, 1, 16119.

9 N. Zhang, F. Cheng, J. Liu, L. Wang, X. Long, X. Liu, F. Li and J. Chen, Nat. Commun., 2017, 8, 405.

10 W. Sun, F. Wang, S. Hou, C. Yang, X. Fan, Z. Ma, T. Gao, F. Han, R. Hu, M. Zhu and C. Wang, J. Am. Chem. Soc., 2017, 139, 9775-9778. 
11 W. Qiu, Y. Li, A. You, Z. Zhang, G. Li, X. Lu and Y. Tong, J. Mater. Chem. A, 2017, 5, 14838-14846.

12 N. Zhang, Y. Dong, M. Jia, X. Bian, Y. Wang, M. Qiu, J. Xu, Y. Liu, L. Jiao and F. Cheng, ACS Energy Lett., 2018, 3, 1366-1372.

13 F. Wan, L. Zhang, X. Dai, X. Wang, Z. Niu and J. Chen, Nat. Commun., 2018, 9, 1656.

14 K. W. Nam, S. Kim, S. Lee, M. Salama, I. Shterenberg, Y. Gofer, J.-S. Kim, E. Yang, C. S. Park, J.-S. Kim, S.-S. Lee, W.-S. Chang, S.-G. Doo, Y. N. Jo, Y. Jung, D. Aurbach and J. W. Choi, Nano Lett., 2015, 15, 4071-4079.

15 Y. Tian, W. Zhang, S. Cong, Y. Zheng, F. Geng and Z. Zhao, Adv. Funct. Mater., 2015, 25, 5833-5839.

16 X. Sun, V. Duffort, B. L. Mehdi, N. D. Browning and L. F. Nazar, Chem. Mater., 2016, 28, 534-542.

17 T. Koketsu, J. Ma, B. J. Morgan, M. Body, C. Legein, W. Dachraoui, M. Giannini, A. Demortière, M. Salanne, F. Dardoize, H. Groult, O. J. Borkiewicz, K. W. Chapman, P. Strasser and D. Dambournet, Nat. Mater., 2017, 16, 1142-1148.

18 X. Ji, J. Chen, F. Wang, W. Sun, Y. Ruan, L. Miao, J. Jiang and C. Wang, Nano Lett., 2018, 18, 6441-6448.

19 F. Wang, W. Sun, Z. Shadike, E. Hu, X. Ji, T. Gao, X.-Q. Yang, K. Xu and C. Wang, Angew. Chem., Int. Ed., 2018, 57, 1197811981.

20 D. Kundu, S. Hosseini Vajargah, L. Wan, B. Adams, D. Prendergast and L. F. Nazar, Energy Environ. Sci., 2018, 11, 881-892.

21 E. Levi, M. D. Levi, O. Chasid and D. Aurbach, J. Electroceram., 2009, 22, 13-19.

22 E. Levi, Y. Gofer and D. Aurbach, Chem. Mater., 2010, 22, 860-868.

23 S. Liu, J. J. Hu, N. F. Yan, G. L. Pan, G. R. Li and X. P. Gao, Energy Environ. Sci., 2012, 5, 9743.

24 F. Wang, Z. Liu, X. Wang, X. Yuan, X. Wu, Y. Zhu, L. Fu and Y. Wu, J. Mater. Chem. A, 2016, 4, 5115-5123.

25 J. R. González, F. Nacimiento, M. Cabello, R. Alcántara, P. Lavela and J. L. Tirado, RSC Adv., 2016, 6, 62157-62164.

26 Y. Liu, S. Sang, Q. Wu, Z. Lu, K. Liu and H. Liu, Electrochim. Acta, 2014, 143, 340-346.

27 S. Sang, Y. Liu, W. Zhong, K. Liu, H. Liu and Q. Wu, Electrochim. Acta, 2016, 187, 92-97.

28 H. Lahan, R. Boruah, A. Hazarika and S. K. Das, J. Phys. Chem. C, 2017, 121, 26241-26249.

29 Y. J. He, J. F. Peng, W. Chu, Y. Z. Li and D. G. Tong, J. Mater. Chem. A, 2014, 2, 1721.

30 M. Kazazi, P. Abdollahi and M. Mirzaei-Moghadam, Solid State Ionics, 2017, 300, 32-37.

31 K. Li, Y. Shao, S. Liu, Q. Zhang, H. Wang, Y. Li and R. B. Kaner, Small, 2017, 13, 1700380.

32 T. Chen and E. Peled, J. Solid State Electrochem., 2017, 21, 3325-3331.
33 C. Wu, S. Gu, Q. Zhang, Y. Bai, M. Li, Y. Yuan, H. Wang, X. Liu, Y. Yuan, N. Zhu, F. Wu, H. Li, L. Gu and J. Lu, Nat. Commun., 2019, 10, 73.

34 M. Kazazi, Z. A. Zafar, M. Delshad, J. Cervenka and C. Chen, Solid State Ionics, 2018, 320, 64-69.

35 Y. Marcus, J. Chem. Soc., Faraday Trans., 1991, 87, 29952999.

36 Z. Rong, R. Malik, P. Canepa, G. Sai Gautam, M. Liu, A. Jain, K. Persson and G. Ceder, Chem. Mater., 2015, 27, 6016-6021.

37 Y.-S. Kim, S. Kriegel, K. D. Harris, C. Costentin, B. Limoges and V. Balland, J. Phys. Chem. C, 2017, 121, 10325-10335.

38 M. Pourbaix, Atlas of electrochemical equilibria in aqueous solutions, National Association of Corrosion Engineers, Houston, Texas, 2d English, 1974.

39 T. Berger, J. A. Anta and V. Morales-Florez, J. Phys. Chem. C, 2012, 116, 11444-11455.

40 G. Rothenberger, D. Fitzmaurice and M. Graetzel, J. Phys. Chem., 1992, 96, 5983-5986.

41 G. Boschloo and D. Fitzmaurice, J. Phys. Chem. B, 1999, 103, 7860-7868.

42 K. M. Krause, M. T. Taschuk, K. D. Harris, D. A. Rider, N. G. Wakefield, J. C. Sit, J. M. Buriak, M. Thommes and M. J. Brett, Langmuir, 2010, 26, 4368-4376.

43 M. J. Brett and M. M. Hawkeye, Science, 2008, 319, 11921193.

44 A. Ghicov, H. Tsuchiya, R. Hahn, J. M. MacAk, A. G. Munoz and P. Schmuki, Electrochem. Commun., 2006, 8, 528-532.

45 L. A. Lyon and J. T. Hupp, J. Phys. Chem. B, 1999, 103, 46234628.

46 F. Fabregat-Santiago, I. Mora-Seró, G. Garcia-Belmonte and J. Bisquert, J. Phys. Chem. B, 2003, 107, 758-768.

47 T. Berger, D. Monllor-Satoca, M. Jankulovska, T. LanaVillarreal and R. Gomez, ChemPhysChem, 2012, 13, 28242875.

48 D. Mandal and T. W. Hamann, Phys. Chem. Chem. Phys., 2015, 17, 11156-11160.

49 C. Costentin and J.-M. Saveant, Chem. Sci., 2019, 5656-5666.

50 Y. Marcus, Chem. Rev., 1988, 88, 1475-1498.

51 S. J. Hawkes, J. Chem. Educ., 1996, 73, 516.

52 H. Lindström, S. Södergren, A. Solbrand, H. Rensmo, J. Hjelm, A. Hagfeldt and S.-E. Lindquist, J. Phys. Chem. B, 1997, 101, 7717-7722.

53 F. Scholz and A. Dostal, Angew. Chem., Int. Ed., 1995, 34, 2685-2687.

54 H. W. Lee, M. Pasta, R. Y. Wang, R. Ruffo and Y. Cui, Faraday Discuss., 2014, 176, 69-81.

55 R. J. Cava, D. W. Murphy, S. Zahurak, A. Santoro and R. S. Roth, J. Solid State Chem., 1984, 53, 64-75.

56 Y. S. Kim, V. Balland, B. Limoges and C. Costentin, Phys. Chem. Chem. Phys., 2017, 19, 17944-17951.

57 CRC Handbook of Chemistry and Physics, ed. D. R. Lide, CRC Press, Boca Raton, FL, Internet V., 2005. 